NBER WORKING PAPER SERIES

\title{
PIPE DREAMS? THE PERFORMANCE OF COMPANIES ISSUING EQUITY PRIVATELY
}

\author{
David J. Brophy \\ Paige P. Ouimet \\ Clemens Sialm \\ Working Paper 11011 \\ http://www.nber.org/papers/w11011
NATIONAL BUREAU OF ECONOMIC RESEARCH
1050 Massachusetts Avenue
Cambridge, MA 02138
December 2004

All authors are from the Stephen M. Ross School of Business at the University of Michigan. Contact Information: 701 Tappan Street; Ann Arbor, MI 48109-1234. E-mails: djbrophy@umich.edu; pshelby@umich.edu; and sialm@umich.edu. We thank Sugato Bhattacharyya, Serdar Dinc, Ken French, Radha Gopalan, Marcin Kacperczyk, Arif Khurshed, Han Kim, Bob Kyle, Tom Nohel, Amit Seru, Sophie Shive, Tyler Shumway, Vijay Singal, Jeremy Stein, Lu Zheng, and seminar participants at the Board of Governors of the Federal Reserve System, the European Financial Management Association Meetings in Basel, the Rutgers Conference on Financial Innovation, the U.S. Securities and Exchange Commission, and the University of Michigan for helpful comments and discussions. We are very grateful to Sagient Research for providing us with the PIPEs data. The views expressed herein are those of the author(s) and do not necessarily reflect the views of the National Bureau of Economic Research.

(C) 2004 by David J. Brophy, Paige P. Ouimet, and Clemens Sialm. All rights reserved. Short sections of text, not to exceed two paragraphs, may be quoted without explicit permission provided that full credit, including () notice, is given to the source. 
PIPE Dreams? The Performance of Companies Issuing Equity Privately

David J. Brophy, Paige P. Ouimet, and Clemens Sialm

NBER Working Paper No. 11011

December 2004

JEL No. G1, G2, G3

\section{ABSTRACT}

Private Investments in Public Equity (PIPEs) have become an important source of financing for young, publicly traded firms whose poor operating performance may limit alternative financing options. We propose that firms are motivated to sell these securities to minimize costs associated with asymmetric information. We find that both the security structure and the investor composition of a PIPE security matter in the subsequent performance of the issuing firm. Poor post-issuance performance is associated with securities where investors obtain significant repricing rights, which protect them from future stock price declines. Furthermore, companies that obtain financing from hedge funds tend to under-perform companies that obtain financing from other institutional investors. We argue that hedge funds act as investors of last resort, playing an important role in the market for young, high-risk firms with substantial asymmetric information. Hedge funds are willing to fund such high-risk companies because they can protect against possible price declines in the issuing companies by either negotiating PIPE securities with repricing rights or by entering into short positions of the underlying stocks of the issuing companies.

David J. Brophy

Stephen M. Ross School of Business

University of Michigan

701 Tappan Street

Ann Arbor, MI 48109-1234

djbrophy@umich.edu

Paige P. Ouimet

Stephen M. Ross School of Business

University of Michigan

701 Tappan Street

Ann Arbor, MI 48109-1234

pshelby@umich.edu
Clemens Sialm

Stephen M. Ross School of Business University of Michigan

701 Tappan Street

Ann Arbor, MI 48109-1234

and NBER

sialm@umich.edu 


\section{Introduction}

Over the past several years, private investments in public equity (PIPEs) have become an increasingly popular alternative to public equity offerings as a source of capital for small- and medium-size public companies whose poor operating performance and high degree of asymmetric information may limit alternative financing options. PIPE transactions are completed within relatively short time periods with fewer regulatory requirements than Secondary Equity Offerings (SEOs). The increasing importance of these securities - \$77 billion was raised in 5,260 transactions between 1995 and 2002 - indicates that firms value these characteristics. However, their popularity has come with controversy. PIPE securities recently have obtained unfavorable attention in reaction to the poor performance of some firms following the issuance of PIPE securities. ${ }^{1}$ We attempt to shed light on this controversy by arguing that PIPEs are a heterogeneous group of securities bought by a variety of investors. We find that both the security structure and the investor composition matter for the subsequent performance of the issuing companies.

PIPEs are financial contracts negotiated directly, or through financial intermediary agents, with a small number of investors. This allows the investors and the issuing companies to customize the specific security structure according to their preferences. We distinguish between two basic security structures: traditional and structured PIPEs. Traditional PIPEs are private placements of common stocks or fixed convertibles at predetermined prices or conversion ratios. Investors in traditional PIPEs receive a fixed number of common stocks or can convert their convertible securities into a fixed number of common stocks of the issuing company. Investors are attracted to these issuances since the equity is typically issued at a discount relative to the market price. On the other hand, structured PIPEs are private placements of variable convertibles at conversion ratios that depend on the performance of the underlying stock after the PIPE issuance. Structured PIPEs enable investors to convert their PIPE securities into a larger number of common stocks if the stocks perform poorly after the issuance date, thus effectively protecting investors against price declines. Though investments in traditional PIPEs are sensitive to changes in the value of the underlying common stock, investments in structured PIPEs are protected against value declines through a variable conversion ratio.

\footnotetext{
${ }^{1}$ Examples of recent negative media attention include "Pipe Dream or Problem?”, The New York Times, June 5, 2004, and “SEC Probes Hedge Funds, Brokers On `Pipe' Offerings”, The Wall Street Journal, July 8, 2004.
} 
In this paper, we document that companies issuing PIPEs, in general, and structured PIPEs, in particular, tend to be young firms in high-growth or high-risk sectors, where market imperfections are most prevalent. These qualities complicate external assessments, resulting in significant information asymmetries between firm insiders and the external market. Myers (1984) and Myers and Majluf (1984) propose that the presence of informational asymmetries can reduce the value at which firms are able to sell their securities. They argue that such firms should issue informationally insensitive securities, such as conventional debt. However, these same attributes restrict such firms in their dealings in the debt market due to higher probabilities of and costs associated with financial distress. Instead, PIPEs may be the optimal solution for these firms. Since PIPEs are sold to a limited number of qualified investors, issuing a PIPE as compared to an SEO can reduce the issuing costs associated with information production. ${ }^{2}$ Furthermore, as argued by Stein (1992), structured PIPEs with their variable conversion price, may be the ideal security design in the presence of information asymmetries, potentially making these securities "adverse selection-proof." Structured PIPEs, although equity securities, can be structured to be as informationally insensitive as straight debt, with smaller costs of financial distress.

Though PIPEs may theoretically be an ideal source of financing for firms with a high degree of asymmetric information, arguments also have been made that these contracts, in particular structured contracts, are faulty and leave the issuing firm prey to market manipulation. Hillion and Vermaelen (2004) argue structured PIPEs are imperfect contracts since investors may have the incentive to engage in manipulative short selling to receive a larger numbers of shares. The U.S. Securities and Exchange Commission has expressed concern after investigating cases of market manipulation surrounding the issuance of variable convertible PIPEs and has warned that these securities present the temptation for investors "to engage in manipulative short selling of the issuer's stock in order to receive more shares." ${ }^{3}$ Corporate executives appear to have heeded this advice since issuances of structured PIPEs have declined substantially in the last years, while issuances of traditional PIPEs have grown.

\footnotetext{
${ }^{2}$ The cost of information production as it relates to the decision to sell equity privately versus publicly is explored in Chemmanur and Fulghieri (1999). Habib and Johnsen (2000) discuss the private placement of debt and outside equity as an information revelation mechanism.

${ }^{3}$ See http://www.sec.gov/news/press/2003-26.htm.
} 
In this paper, we focus on the stock-market and accounting performance of companies issuing equity privately. We do not discuss the choice between public and private issuances of equity and debt securities. ${ }^{4}$ We analyze the 5,260 PIPE transactions issued between 1995 and 2002. We argue that PIPEs are a heterogeneous group of securities bought by a variety of investors. Approximately one-third of the transactions are structured PIPEs. Hedge funds are the main investors in the PIPEs market and account for almost one-quarter of the total investments. We find that hedge funds tend to focus their investments in structured PIPEs, where they are effectively protected against price declines of the issuing companies: Hedge funds account for 72 percent of the investments in structured PIPEs and for just 16 percent of the investments in traditional PIPEs.

Using a multinomial logit model, we explain the interaction of traditional and structured PIPEs with hedge and non-hedge fund investors as a function of issuer characteristics. We find that companies where information asymmetries are typically assumed to be more important are more likely to raise capital through structured PIPEs and are more likely to raise capital from hedge funds. We also find that venture capital-backing in the pre-IPO period is an important predictor of the security structure and investor composition, confirming Brav and Gompers (1997), who show that venture capital-backing benefits companies even beyond the IPO.

We show that the stock price and the accounting performance are related to the specific security structure (traditional vs. structured PIPEs) and the category of the investors (hedge fund vs. non-hedge fund investors). In the short term, the average PIPE studied has an average abnormal return of 3.87 percent over a 10-day event window around the closing date of the deal, confirming previous results on private placements by Wruck (1989). Furthermore, consistent with Hertzel, Lemmon, Linck, and Rees (2002), we find the counter-intuitive result that PIPE issuers, on average, experience negative long-term returns after positive announcement returns. The poor long-term performance of companies issuing PIPEs confirms Barclay, Holderness, and Sheehan (2003) and Wu (2004), who document that investors in private placements are typically passive and do not appear to increase firm value through monitoring.

\footnotetext{
${ }^{4}$ Gomes and Phillips (2004) discuss in a recent working paper the choice between private and public security issuances by publicly traded companies.
} 
Our paper is the first paper that analyzes the impact of the security structure and the investor composition on the performance of companies issuing PIPEs. We demonstrate that there is substantial heterogeneity in the performance of PIPE companies. We find that firms issuing structured PIPEs under-perform firms issuing traditional PIPEs in both the short (0.40 vs. 5.49 percent) and the long term (-38.83 vs. -13.03 percent). Our results of the dismal long-term performance of variable convertible private placements are consistent with Hillion and Vermaelen (2004), who analyze the performance of “death-spiral convertibles,” a specific form of structured PIPEs.

Our most interesting results show that the investors in the security matter. Though we find no abnormal performance in firms issuing traditional PIPEs sold to non-hedge fund investors, we find a significant negative abnormal performance following the PIPE issuance if the traditional security is bought by a hedge fund. These results are consistent with Krishnamurthy, Spindt, Subramaniam and Woidtke (2004) who show that private placements which include an affiliated investor (defined as officers, directors, or affiliated institutions and individuals) have no long-run declines in contrast to negative long-run returns when a private placement is sold to unaffiliated investors.

Having a dataset with both structured and traditional PIPEs as well as the identity of the investor lets us test whether the poor performance of companies issuing structured PIPEs occurs because of manipulative short selling by technical investors, which reduces the long-term value of the issuing companies, or whether PIPEs are issued by companies in financial distress that are subject to substantial asymmetric information. By separating between PIPEs sold to hedge fund investors (which tend to extensively use short positions and derivatives) as compared to other institutional investors such as corporations, mutual funds, and venture capital firms (which do not tend to use short positions and derivatives as frequently), we are able to distinguish between a faulty contract being manipulated by an aggressive investor and a troubled firm selling the only viable security given the existence of substantial asymmetric information.

The extraordinarily poor performance of companies issuing structured PIPEs, which are primarily associated with hedge fund investors, could indicate that hedge fund investors cause the price declines, possibly through manipulative short-selling. However, we do not find that short-selling pressure is greater for companies issuing structured PIPEs than for companies issuing traditional PIPEs. Moreover, companies issuing structured PIPEs purchased by hedge 
funds do not tend to perform significantly worse than companies issuing structured PIPEs purchased by other investor classes. These results cast doubt on the hypothesis that hedge fund investors systematically manipulate stock prices of companies issuing structured PIPEs by shortselling the underlying stock. Further, we document that hedge funds tend to invest in companies that are relatively more liquid and have higher trading volumes, conditions opposite to those most conducive for successful stock price manipulation.

We propose that hedge funds act as investors of last resort for firms with the fewest alternatives captured by negative operating performance, large capital needs, and a high degree of asymmetric information. Hedge funds are often only willing to invest in companies with substantial asymmetric information, because they are able to hedge the downside risk by either negotiating PIPE securities with repricing rights or by entering into short positions of the underlying stocks of the issuing companies. This is in sharp contrast to other investors, such as mutual and pension funds, where regulatory requirements limit the use of such strategies. ${ }^{5}$ Hedge fund investors can still benefit from these investments, even if they are completely hedged, because companies issue PIPEs at significant discounts from market prices.

However, it is these same attributes which make hedge funds efficient investors in PIPEs which also might lead those firms isusing PIPEs with multiple investor options to avoid selling to hedge funds. Firms with interested mutual fund, corporation, or venture capital investors may prefer these investors over hedge funds to avoid expected increases to the outstanding short interest in their firm or out of concern that the hedge fund will manipulate their equity prices. Firms also could be seeking a certification from these non-hedge investors as first hypothesized by Booth and Smith (1986).

The remainder of the paper is structured as follows: In Section 2, we give a general overview of PIPE securities. Section 3 describes our data sources and provides summary statistics of the PIPE transactions. Section 4 analyzes the determinants of the investor and the security structure choice using a multinomial logit estimation. Section 5 analyzes the impact of the security structure on the short- and long-term stock price performance of the issuing companies. Section 6 discusses the impact of the investor composition on the stock price performance. Section 7 confirms our event-study results using calendar-time portfolios

\footnotetext{
${ }^{5}$ Ackermann, McEnally and Ravenscraft (1999) analyze the characteristics of hedge funds relative to other investors, which enable them to follow more sophisticated trading strategies.
} 
controlling for common variation in risk levels and risk premia (Ferson and Schadt, 1996) and for the impact of equity issuances on the fundamentals of firms following (Eckbo, Masulis, and Norli, 2000). In Section 8, we show that the accounting performance of companies issuing PIPEs is generally consistent with the stock price performance. Section 9 studies the short interest of companies issuing PIPEs and Section 10 provides a brief conclusion.

\section{PIPE Securities}

The specific characteristics of each PIPE transaction are negotiated between the investors and the issuing companies. Thus, there are numerous different security structures of PIPE securities. We distinguish between two basic security structures: Traditional and structured PIPEs. We describe in Appendix A additional details of these securities.

\subsection{Traditional PIPEs}

Traditional PIPEs include private placements of common stock, fixed convertible preferred stock, and fixed convertible debt. In a common stock PIPE a fixed number of shares is issued and sold at a predetermined discount or premium to the market price. ${ }^{6}$ The future value of the investor's position increases proportionally with the stock price. Investors in common stock PIPEs are exposed to future stock price declines because they cannot immediately dispose of their shares due to lock-up periods. However, they can hedge their risk by simultaneously taking out short positions in the underlying stocks. In this case, investors can capture the discount while minimizing the risk exposure.

Fixed convertibles yield a current return through interest or dividend payments and can be converted into a fixed number of shares of the company's common stock at a predetermined conversion ratio. If the future stock price is above the conversion price, then the value of a convertible security is proportional to the value of the common stock; otherwise, the PIPE security is not converted into common stock. This inherent protection against decreases in equity prices can partially mitigate some of the concerns for investors regarding asymmetric information. Many hedge funds follow convertible arbitrage strategies by purchasing a fixed

\footnotetext{
${ }^{6}$ Discounts are suggested to reflect compensation to investors for expected monitoring services and advice (Wruck, 1989), illiquidity (Silber, 1991), information production (Hertzel and Smith, 1993), and entrenchment (Barclay, Holderness, andSheehan, 2003).
} 
convertible security and simultaneously dynamically hedging the risk exposure. In this case, they can take advantage of the effective discount provided by the convertible security.

\subsection{Structured PIPES}

Structured PIPEs are issues of equity, where the investor can convert the PIPE security into a variable number of common stocks during the conversion period (e.g., floating or reset convertible debt or preferred stock PIPE). A basic structured PIPE is a variable convertible, where the conversion price is based on market prices of the common stock during a fixed time period following the issuance. This feature protects the investor if the price of the common stock decreases after the PIPE deal is closed, since the investor will receive a larger number of shares following a decreasing stock price. For example, a basic variable convertible states that the convertible security can be redeemed for common stock with a fixed value $V$ on the conversion date. Thus, if the stock price during the future conversion period ${ }^{7}$ is $p$, then the company would issue $V / p$ shares to the owner of the floating convertible. The implication of this security is that decreasing stock prices will result in greater dilution of existing shareholders. Variable convertibles often include caps and floors that limit the possible range of conversion prices.

This variable security is essentially “adverse-selection-proof” equity (Stein, 1992), because all parties in the transaction can agree that this security has a fixed value of $V$ on the conversion date - assuming the firm does not declare bankruptcy before the maturity date of the security. These re-pricing rights are effectively very similar to an embedded short position, which immunizes the investors from changes in the price of the underlying stock after the PIPE issuance.

One disadvantage of a floating convertible is that this security might be subject to market manipulation, particularly for stocks that are not very liquidly traded. For example, by short selling the underlying equity shares during the conversion period, PIPE investors might be able to temporarily depress stock prices, resulting in a more favorable conversion ratio. In such an instance, variable PIPE investors would receive a larger number of common stocks through the convertible security and this excessive dilution would permanently reduce the stock value for the original stockholders, as discussed by Hillion and Vermaelen (2004). 


\section{Data and Summary Statistics}

This section describes the data sources and summarizes the main characteristics of our data set.

\subsection{Data Sources}

Our data set on PIPE transactions was provided by Sagient Research in San Diego, California. They collect data on all registered and publicly announced private placements since 1995. The data includes detailed information on the specific characteristics of PIPE transactions and their investors. All the information from Sagient Research comes directly from SEC filings and public announcements made by the companies. ${ }^{8}$ Our final dataset includes 5,260 PIPE transactions.

\subsection{Characteristics of PIPE Transactions}

The PIPEs market has increased substantially between 1995 and 2002. The composition of the deals has changed considerably over time. Between 1995 and 1998, structured PIPEs accounted for 53.0 percent of the PIPE transactions and for 36.9 percent of the capital raised. Between 1999 and 2002, structured PIPEs accounted for just 24.4 percent of the PIPE transactions and for just 10.3 percent of the total proceeds. The decrease in the number of structured PIPEs continued in 2003 and early 2004. This fast rise and the subsequent decline in the proportion of structured PIPEs is one example of a failed financial innovation. On the other hand, traditional PIPEs remained an important source of funding for companies during the weak equity market between 2000 and 2002.

Panel A of Table 1 summarizes the characteristics of the PIPE securities issued between 1995 and 2002. These PIPE deals raised a total of \$76.7 billion. Traditional PIPEs account for the highest proceeds raised through PIPE transactions. The 3,592 traditional PIPEs raised \$65.0

\footnotetext{
${ }^{7}$ The conversion period can be as short as one day or as long as the lifetime of the security. The conversion period is typically between one and four weeks. Prices calculated as an average during the conversion period are then used to determine the number of new shares to be issued upon conversion of the variable security.

${ }^{8}$ We exclude Regulation S and 144-A placements. Regulation S placements are purchased by foreign institutional investors and have become less prevalent because of changes to SEC regulations. 144-A placements are issued by larger and more mature companies and are not considered PIPEs due to different regulatory treatments. Our qualitative results are not affected if we include the Reg S and the 144-A transactions. We exclude 95 Reg S placements and 469 144-A placements.
} 
billion and the 1,668 structured deals raised $\$ 11.8$ billion. The PIPE transactions increase the funds available for companies substantially: The average ratio of the proceeds of a PIPE and the market capitalization of the company exceeds 20 percent. The number of investors per deal ranges between one and 84, with most PIPE transactions having only one investor. Many companies are involved in multiple PIPE transactions over our sample period. 1,560 companies issue exactly one PIPE, whereas 1,134 companies issue more than one PIPE.

Panel B of Table 1 summarizes the composition of the investors in PIPE securities. The investors can be identified for more than 80 percent of the capital raised in our sample. Each investor is classified in one of 11 different groups. Hedge funds are the largest investor class, accounting for 24.57 percent of the total investments in PIPE securities by identified investors. Corporations, mutual funds and institutional advisors, venture capital, and private equity funds are also important investors in this market.

The investor composition differs dramatically between the two basic security structures. Hedge funds account for 15.63 percent of the investment in traditional PIPEs and for 71.72 percent of the investment in structured PIPEs with known investor classifications. The other investors belong to various groups of institutional investors.

Sagient Research categorizes the companies issuing PIPEs into 11 industries listed in Panel C. Most companies issuing PIPEs are in high-tech industries, such as communications, healthcare, consumer cyclicals, and technology.

\subsection{Merge with CRSP, Compustat, SDC Databases, $I / B / E / S$, and Short Interest Data}

To obtain accounting and stock price measures of companies issuing PIPEs, we match our PIPE data set with the CRSP/Compustat databases using the ticker symbols and the names of the issuing companies. We can match almost all PIPE companies that are traded on the NYSE, NASDAQ, and AMEX to CRSP. However, we are usually not able to match companies that are traded Over-the-Counter (Bulletin Board). Of the 5,260 PIPE transactions, 914 companies cannot be found in CRSP. These un-matched transactions raise less than 5 percent of the total proceeds of PIPE transactions. We are able to match most of the companies in our sample to the Compustat database.

We also identify public equity and public debt issuances between 1990 and 2003 using the SDC database and merge this dataset with our data. We further identify whether companies 
which went public within five years of the PIPE issuance are venture-backed or not. We also obtain the number of analysts making EPS forecasts for PIPE companies three months prior to the PIPE issuance according to I/B/E/S. Finally, we obtain data on the monthly volume-weighted short positions of stocks listed on NYSE, AMEX, and NASDAQ directly from the respective stock exchanges. We match these short-interest data with our sample of PIPE companies.

\section{Security and Investor Choice}

Companies issuing PIPEs select simultaneously the investors and the specific security structure. In this section, we summarize the characteristics of companies issuing PIPEs and we study the security and investor choice using a multinomial logistic regression.

\subsection{Characteristics of PIPE Companies}

PIPE issuers tend to be young, small, growth companies in high-technology sectors. Table 2 summarizes characteristics of firms issuing PIPEs. Panel A reports several stock market measures prior to the issuance of the PIPE transactions.

Companies issuing PIPEs tend to be relatively young small companies. ${ }^{9}$ The majority of companies were listed less than five years prior to the issuance of a PIPE transaction. Companies issuing traditional PIPEs are slightly older than companies issuing structured PIPEs. We test for the differences in the characteristics of structured and traditional PIPEs using a $t$-test for the means assuming unequal variances and using a non-parametric Fisher test for the medians. Companies issuing PIPEs have, in general, significantly lower market capitalization than companies traded on the three major U.S. exchanges. The average company has a market capitalization of $\$ 183.7$ million. Companies issuing structured PIPEs tend to be significantly smaller than companies issuing traditional PIPEs.

We find a substantial cross-sectional difference in the stock price performance in the year prior to the PIPE issuance. The median stock price decreases by 17.8 percent, while the mean stock price increases by 30.0 percent, indicating that a relatively small number of PIPE companies appreciate dramatically in the year prior to the issuance. The returns of PIPE companies tend to be considerably more volatile than the returns of companies listed on major U.S. exchanges. While companies traded on the NYSE, AMEX, and NASDAQ have a median

\footnotetext{
${ }^{9}$ For each company we determine the age relative to the fist listing in the CRSP database.
} 
annualized standard deviation of daily returns of 48 percent between 1995 and 2002, PIPE companies have a median volatility of 68 percent in the year prior to the PIPE issue. The volatility does not differ much between the two security structures. However, companies issuing structured PIPEs have significantly higher annual turnovers and higher short interest positions compared to other PIPE companies.

Only 31.6 percent of PIPE issuing companies have analyst coverage, and the mean number of analysts per PIPE firm is 1.1. Companies issuing structured PIPEs have significantly less analyst coverage than companies issuing traditional PIPEs. Since the number of analysts following a security is often used as a proxy for asymmetric information, ${ }^{10}$ this difference confirms our view that companies issuing structured PIPEs are potentially more subject to informational asymmetries.

Brav and Gompers (1997) show that venture capital backing adds value even after the initial public offering: Venture-backed companies substantially outperform non-venture-backed firms in the public aftermarket. In our sample, 27.9 percent of the PIPE companies that went public during the five years prior to the PIPE issuance are venture-backed. Companies that issue structured PIPEs are significantly less likely to be venture-backed than companies that issue traditional PIPEs, indicating that venture backing also has an impact on the opportunities to raise funds.

Panel B reports several accounting measures during the fiscal year prior to the issuance of the PIPE transactions. ${ }^{11}$ Companies issuing PIPEs differ substantially from companies in Compustat. Companies in our sample experience very poor operating performance during the fiscal year prior to the issuance of the PIPEs. The return on equity for the median company issuing a PIPE is -62.7 percent. On the other hand, the median company in Compustat has a return on equity of 7.8 percent during the same period. ${ }^{12}$ We obtain similar results using returns

\footnotetext{
${ }^{10}$ See Brennan and Subrahmanyam (1995), Aboody and Lev (2000) and Wu (2004). Diether, Malloy, and Scherbina (2002) show that the dispersion of the earnings forecasts by analysts is a measure of asymmetric information. We also find that companies issuing structured PIPEs have a significantly higher dispersion of earnings forecasts than companies issuing traditional PIPEs. However, we do not use this alternative proxy of asymmetric information, since this dispersion information is often not available for our sample of PIPE companies because 79.6 percent of PIPE companies have no or only one analyst following their earnings.

${ }^{11}$ We give the exact definitions of the accounting variables in Appendix D. All the accounting measures are winsorized at the 1-percent level to eliminate the impact of extreme outliers.

12 PIPE issuing companies tend to be substantially younger than the median company in Compustat, and younger companies tend to have lower profitability. If we match our companies by industry, age, and size, then we can still observe that PIPE issuing companies have considerably worse profitability. For example, the median return on
} 
on assets. Though 71.0 percent of companies in Compustat have positive returns on assets, only 15.1 percent of companies issuing PIPEs have positive returns on assets. The profitability of the median company issuing structured PIPEs is worse than the profitability of the median company issuing traditional PIPEs.

The median company issuing a PIPE has assets valued at \$26.1 million, while the median company in Compustat has assets valued at $\$ 146$ million. The book-to-market ratio of the median PIPE company (22.4 percent) is substantially lower than the book-to-market ratio of the median company in Compustat (52.0 percent). PIPE companies also have lower market leverage than the median company in Compustat. Companies issuing structured PIPEs tend to have fewer total assets, lower book-to-market ratios, and lower leverage than the median company issuing traditional PIPEs.

Companies issuing PIPEs make substantial capital expenditure and research and development investments despite their poor operating performance. We do not find that companies issuing structured PIPEs have significantly different capital expenditure and research and development investments. These companies need to raise external funds to maintain their investment levels. The dismal operating performance may pose difficulties in raising capital through public debt markets and secondary equity offerings. According to SDC, just 0.20 percent of PIPE companies issue public debt and 3.2 percent of PIPE companies make secondary equity offerings in the year of PIPE transactions. This supports our earlier contention that firms that issue PIPEs are limited in their abilities to raise financing in the more conventional public debt and equity markets.

\subsection{Multinomial Logit Estimation}

To better understand the security and investor choice, we estimate a multinomial logit model, which is also known as a polytomous logistic regression. This estimation method allows us to explore the determinants of the security and investor structure for PIPE issuances. We sort all PIPE transactions with known investors into four groups based on the two security structures (traditional and structured PIPEs) interacted with the two investor groups (hedge fund and nonhedge fund investor). A PIPE is classified as having a hedge fund investor if hedge funds

equity of matched companies is 2.7 percent, which is economically and statistically significantly different from the median return on equity of PIPE companies of -62.7 percent. 
account for more than 50 percent of the proceeds in a particular PIPE. PIPE transactions where the investor identity is unknown for more than 50 percent of the proceeds are not considered. ${ }^{13}$ The first group (traditional PIPE and non-hedge investor) is the largest and accounts for 47.8 percent of the observations, while the third group (structured PIPE and non-hedge investor) is the smallest and accounts for 8.1 percent of the observations. Thus, we have multiple possible outcomes $y=\{1,2,3,4\}$. The numerical values of the dependent variable in a multinomial logit estimation are arbitrary since the outcomes are "unordered.”

The vector of independent variables, $X$, includes several characteristics of the companies issuing PIPEs, year- and industry-fixed effects. All these explanatory variables are taken prior to the closing of the PIPE transaction. The accounting variables are taken at the end of the fiscal year prior to the PIPE issuance.

In the multinomial logit model, we estimate the coefficient vectors $\beta^{1}, \beta^{2}, \beta^{3}$, and $\beta^{4}$, corresponding to the four outcome categories:

$$
\operatorname{Pr}(y=i)=\frac{e^{X \beta^{i}}}{\sum_{j=1}^{4} e^{X \beta^{j}}} \quad \text { for } \quad i \in\{1,2,3,4\}
$$

To ensure that the model is identified, we use traditional PIPEs with non-hedge fund investors $(y=1)$ as the comparison group by setting the vector $\beta^{1}$ to zero. For example, the relative probability of issuing a traditional PIPE from hedge fund investors $(y=2)$ compared to issuing a traditional PIPE from non-hedge fund investors $(y=1)$ is as follows:

$$
\frac{\operatorname{Pr}(y=2)}{\operatorname{Pr}(y=1)}=e^{X \beta^{2}} .
$$

Table 3 summarizes the results for the maximum-likelihood multinomial logit estimations. The first column reports the coefficient vector $\beta^{2}$ and compares the companies that issue traditional PIPEs to hedge funds relative to the companies that issue traditional PIPEs to non-hedge fund investors. The second and the third columns report the coefficient estimates $\beta^{3}$ and $\beta^{4}$, respectively.

\footnotetext{
${ }^{13}$ Our results are not affected significantly if we use different cutoff levels for hedge fund investors or if we either include the unknown investors to the hedge fund group or to the non-hedge fund group.
} 
We observe that smaller companies are relatively more likely to raise capital through structured PIPEs and hedge funds rather than through traditional PIPEs and other investors, because the coefficient on the logarithm of the market value is significantly negative for group 4 . The coefficients on the book-to-market ratio are negative for all three groups. This indicates that companies with higher book-to-market ratios (value companies) tend to be more likely to raise capital through traditional PIPEs from non-hedge fund investors, while lower book-to-market ratios (growth companies) tend to raise capital either through structured PIPEs or from hedge fund investors. We also observe that companies with less extensive analyst coverage are relatively more likely to obtain financing from hedge funds. An important predictor of the security structure and the investor composition is the indicator variable of whether the company has been venture-capital funded. We find that venture-funded companies are substantially less likely to issue structured PIPEs. Brav and Gompers (1997) argue that venture-backed firms might be less subject to asymmetric information. Thus, companies where asymmetric information is potentially more important (i.e., smaller companies with relatively smaller book values and companies with less analyst coverage) are relatively more likely to issue variable convertibles and to obtain financing from hedge funds.

The multinomial logit results suggest that companies receiving funding from hedge funds tend to have significantly higher trading volumes and slightly higher short interest six months prior to the PIPE issuance. Although the coefficients on the trading volume are statistically significant at the 1 percent level, the coefficients on the short interest are usually not significant at conventional significance levels. Hedge funds are interested in trading liquid securities and they choose to invest in companies with high volumes, which can be short-sold easily. These results cast some doubt on the hypothesis that hedge fund investors systematically seek companies whose prices can be more easily manipulated, since companies with low trading volume and with a non-existent short-selling market might be more susceptible to market manipulation. 


\section{The Impact of Security Structure on the Performance of Issuing Companies}

This section studies the short- and long-term stock performance of companies that issue PIPEs. The stock return analysis estimates the returns that original shareholders of common stocks would have experienced had they held their stocks for several years post-issuance. The return of these original investors will, in general, be different from the return of the new investors who purchase the PIPEs. Unfortunately, we cannot compute the returns of the investors in these transactions for several reasons: First, PIPEs are usually sold at significant discounts and often include warrants and repricing rights. We do not have sufficiently detailed information to price these various security components and to determine the effective purchase prices for the investors. Second, we do not know when the investors exercise their conversion rights and liquidate their positions. Thus, we cannot compute holding period returns for the different investors. Third, we do not observe whether the investors hold other positions in the issuing firm. Many investors, especially hedge funds, often acquire short positions in the common stocks of the issuing companies to hedge their risk exposure. Thus, hedged institutional investors might not be affected significantly if the companies they invest in experience poor long-term returns.

\subsection{Estimation Methodology}

In this section, we estimate the performance of the common stocks of companies issuing PIPEs. We follow Barber and Lyon (1997) and benchmark performance by using a single control firm for each PIPE firm. We analyze the performance of the stock price during a four-year window around the closing of the PIPE transaction. We match each company in our sample to a comparable company according to its industry, market capitalization, book-to-market ratio, and momentum characteristics in the previous month, as described in more detail in Appendix B.

Subsequently, we compute daily buy-and-hold returns for all companies during a 1,000 trading day window around the closing date of the PIPE transaction. This window corresponds to roughly two years before and two years after the closing of the transaction. Abnormal returns are defined as the difference between the buy-and-hold return of the PIPE company and the buy-andhold return of the matched company. 


\subsection{Short-Term Stock Price Performance}

The performance of stock prices of PIPE companies for different time windows is summarized in Table 4. Companies issuing PIPEs experience a relatively strong positive return during a 10-day event window around the close of the PIPE transaction (first row labeled [-4, 5]). The average abnormal return of companies issuing PIPEs amounts to 3.87 percent during a 10day event window around the close. ${ }^{14}$ This average return is highly statistically significant. ${ }^{15}$ This result is in contrast to the negative average abnormal return during a short-term window surrounding the announcement of a public offering of seasoned equity. ${ }^{16}$ The appreciation is concentrated around the day of the PIPE close, since most deals are publicly announced on the transaction day after the close of the stock market. The average company issuing a PIPE appreciates by 0.10 percent on the day before the close, by 0.70 percent on the day of the close, and by 1.30 percent on the day after the close.

We find a significant difference in the short-term returns of companies that issue traditional PIPEs and structured PIPEs. Stocks of companies issuing traditional PIPEs have a statistically significant average abnormal return of 5.49 percent. On the other hand, stocks of companies issuing variable PIPEs have an average abnormal return of 0.40 percent, which is not significantly different from zero.

\subsection{Long-Term Stock Price Performance}

Figure 1 depicts the average abnormal returns for the companies issuing the three basic security structures during the two years before and after the closing. The returns are normalized to zero on the closing day. Similarly to Hertzel et al. (2002), we find a negative relation between short- and long-term returns for traditional PIPEs. Though PIPE issuing companies experience, on average, a positive short-term announcement performance, they experience a negative longterm performance. However, we find the stock price performance differs dramatically between the two security structures. Companies issuing traditional PIPEs experience mean abnormal returns of -10.9 percent during the subsequent 500 days. On the other hand, the stock prices of firms issuing structured PIPEs start declining on the first day after the issuance day and decrease,

\footnotetext{
${ }^{14}$ This result is similar to Wruck (1989), Fields and Mais (1991), Hertzel and Smith (1993), Varma and Szewczyk (1993), Hertzel et al. (2002), and Wu (2004).

${ }^{15}$ The statistical significance levels are computed using the standard $t$-tests.
} 
on average, by 36.1 percent relative to matched firms. The results for the structured PIPEs are similar to the ones reported by Hillion and Vermaelen (2004), who study floating convertible PIPEs issued between January 1995 and August $1998 .^{17}$

Table 4 divides the long-term performance of the stock returns after the PIPE issuance into three different time periods, (i.e., [6, 100], [6, 250], and [6, 500]). ${ }^{18}$ We observe that companies issuing PIPEs have negative abnormal returns during the three intervals after the closing of the deal, which are economically and statistically significant. The abnormal returns are particularly poor for companies issuing structured PIPEs. A similar long-term underperformance is also found for initial public offerings ${ }^{19}$ and for seasoned equity offerings. ${ }^{20}$ Companies issuing structured PIPEs experience a substantial deterioration of their stock valuations over the two years considered here. These abnormal returns are economically and statistically highly significant. On the other hand, the underperformance of companies issuing traditional PIPEs is less pronounced, particularly during the first year following the PIPE issuance. Appendix C shows that the statistical inference is not affected much if we estimate the standard errors using bootstrap-simulations instead.

One surprising result remains the slow stock price adjustment after the PIPE issuance. We would anticipate a market correction to occur at the time of the announcement of the security structure and the investor composition. One explanation for our results could be a slow release of information of the security structure and the investor composition. However, PIPEs are regulated by the SEC, and firms must submit the required forms to the SEC within 15 calendar days. This indicates that market prices do not adjust sufficiently rapidly to the announcement of structured PIPEs and that investors could pursue profitable trading strategies by short-selling securities after the announcement of a structured PIPE.

\footnotetext{
${ }^{16}$ See, for example: Smith (1986), Asquith and Mullins (1986), Masulis and Korwar (1986), Mikkelson and Partch (1986), Shyam-Sunder (1991), and Cornett and Tehranian (1994).

${ }^{17}$ A relatively large number of companies issue multiple PIPEs over our sample period. Thus, the returns of these companies are weighted more heavily. However, our results are not affected significantly if we only look at the first PIPE deal by each company. Moreover, our results do not change qualitatively if we exclude companies with stock prices below $\$ 1$ on the closing day of the transaction or if we exclude companies with market capitalizations below $\$ 10$ million. See Ball, Kothari, and Shanken (1995) for a discussion of potential problems caused by low-price stocks.

${ }^{18}$ The abnormal returns between trading days $[6,500]$ after the PIPE issues include only a portion of the abnormal returns for PIPE issuances in 2002, because we only have available stock return data until December 2003. The results do not change qualitatively if we only analyze the PIPE deals issued between 1995 and 2001, which have complete return series.

${ }^{19}$ See, for example, Ritter (1991) and Loughran and Ritter (1995).
} 


\subsection{Distribution of Long-Term Returns}

We plot in Figure 2 the cumulative probabilities of the abnormal returns during the 250 trading days following the closing of the PIPE deals to investigate whether the averages of the long-term stock price performance are driven by outliers. The cumulative probability function of the abnormal stock returns of traditional PIPE companies lies almost everywhere to the right of the one of structured PIPE companies. The median abnormal stock return is -9.24 percent for traditional and -22.4 percent for structured PIPE companies. In our sample, 56.4 percent of the companies issuing traditional PIPEs experience negative abnormal returns and 66 percent of the companies issuing structured PIPEs experience negative abnormal returns in the following year. We can reject the Kolmogorov-Smirnov tests that the two distributions are identical.

\subsection{Different Benchmark Portfolios}

Table 5 summarizes the short- and the long-term results using six different benchmark portfolios. The first benchmark is the appropriate book-to-market benchmark portfolio according to Fama and French (1992). ${ }^{21}$ The benchmark portfolios, which are constructed at the end of each June, are the intersections of two portfolios formed on size and three portfolios formed on the ratio of book equity to market equity. The second benchmark uses a comparable firm matched by industry and size. We match each PIPE company to a company in the same industry and with the closest market capitalization. The third benchmark uses a comparable firm matched by industry, size, and book-to-market, as described in Appendix B. The fourth benchmark is identical to our base case from Table 5 and matches according to industry, size, book-to-market, and momentum.

The fifth benchmark matches companies also by age to control for return patterns that are age-dependent. In particular, companies that recently did an IPO tend to under-perform their benchmarks as shown previously by Ritter (1991) and Loughran and Ritter (1995). By controlling for age, we eliminate any poor performance that is driven by the IPO underperformance or by any other factors that are age specific. The sixth benchmark computes the relative performance of PIPE companies with companies issuing secondary equity offerings,

\footnotetext{
${ }^{20}$ See, for example, Spiess and Affleck-Graves (1995) and Loughran and Ritter $(1995,1997)$.

${ }^{21}$ The data are obtained from Kenneth French's Web site:
} 
since it also has been shown that companies issuing SEOs tend to under-perform their benchmarks as discussed by Spiess and Affleck-Graves (1995) and Loughran and Ritter (1995, 1997). In a first step, we find for each PIPE and SEO company a comparable company according to industry, size, book-to-market, and momentum and compute the abnormal returns. In a second step, we average the abnormal returns of PIPE and SEO companies and take the difference in the average abnormal returns. This “difference in difference” approach measures whether companies raising equity privately experience different returns from companies raising equity publicly. Eckbo, Masulis, and Norli (2000) argue that a decrease in expected returns of issuing companies might be due to a decrease in the risk exposure which results from a decrease in the leverage of the issuing companies relative to the comparable firms. The difference-in-difference estimate can control for this effect if the risk exposures of companies issuing equity privately and publicly are similarly affected.

Our main conclusions remain generally unaffected using the different benchmarks. We find very strong evidence that companies issuing traditional PIPEs experience positive announcement effects during a short-term event window and that structured PIPEs perform poorly in the long run. The long-term under-performance is negative in all cases for the companies issuing traditional PIPEs. However, we only obtain a marginal statistical significance using the difference-in-difference approach, which compares the abnormal returns of companies issuing equity privately and publicly.

\section{The Impact of Investor Classes on the Performance of Issuing Companies}

The composition of investors differs substantially between the different PIPE structures. Though structured PIPEs are purchased primarily by hedge funds, traditional PIPEs are purchased by various institutional investors. Table 6 summarizes the average abnormal returns of the underlying stocks of companies that issue PIPEs by their main investor classes. We categorize the PIPE transactions depending on whether a specific investor class accounts for more than 50 percent of the total proceeds. Panel A summarizes the short-term abnormal returns and Panel B summarizes the long-term abnormal returns during the two years following the close of the PIPE deal.

http://mba.tuck.dartmouth.edu/pages/faculty/ken.french/Data_Library/six_portfolios.html. 


\subsection{Short-Term Returns}

Booth and Smith (1986) propose that a third party can certify the value of securities issued by a firm with an otherwise uncertain value. If certain classes of investors are able to certify PIPE issuing firms, then we would expect different patterns in short-term gains. We observe in Panel A that companies that receive investments from hedge funds perform considerably worse than companies that receive investments from other investors during the 10day event window. Companies associated with hedge funds appreciate by only 1.42 percent during the 10-day event window, while companies associated with other investors appreciate on average by 5.66 percent. The short-term abnormal returns are particularly large for PIPE transactions where corporations or venture capital and private equity funds are the majority investors. The average 10-day abnormal returns equal 9.38 percent for the transactions where corporations are the major investors and 8.51 percent for the transactions where venture capital or private equity funds are the major investors. This indicates that the investor identity may have an important certification role in the short run.

\subsection{Long-Term Returns}

Panel B of Table 6 summarizes the long-term abnormal returns during the two years following the PIPE transaction. The long-term abnormal returns tend to be lower for companies that obtain financing from hedge fund investors. This result is driven by two factors: First, hedge funds are more likely to invest in structured PIPEs, which are issued by companies for which we have already demonstrated significant post-issuance underperformance as compared to firms which issue traditional PIPEs. Second, companies issuing traditional PIPEs to hedge funds perform worse than companies that issue traditional PIPEs to other investors. However, we find that hedge funds do not have a significantly different impact on long-term stock price performance for companies issuing structured PIPEs.

The poor performance of PIPE companies issuing traditional PIPEs cannot be explained by market manipulation, because investors in traditional PIPEs do not have any opportunity to increase the value of their position through short-selling pressure during the conversion period. Instead, we argue that hedge funds are investors of last resort for troubled firms. At the time of the closing of the PIPE, the market may not have been fully aware of the troubled state of the issuing firm. Subsequently, as the market becomes informed prices decrease. Hedge funds are 
ideally suited to be investors of last resort since they have few restrictions in establishing short positions to hedge any possible downside risk associated with investing in troubled firms.

\subsection{Determinants of Stock Price Performance: Regression Evidence}

This section analyzes the determinants of the performance of PIPE stocks using a regression framework. We analyze whether our results on the impact of security structure and investor composition are robust if we include additional control variables in a multi-variate regression specification. The dependent variable is the excess buy-and-hold return of a PIPE issuing company relative to one of the six Fama-French size and book-to-market portfolios:

$$
X R_{i, t+\Delta}=\beta_{0}+\beta_{1} S P_{i}+\beta_{2} T P_{i} H F_{i}+\beta_{3} S P_{i} H F_{i}+\gamma X_{i}+e_{i, t+\Delta}
$$

The excess return above the corresponding Fama-French portfolio during the event window $\Delta$ is denoted by $X R_{i, t+\Delta}$. The indicator variables $T P_{i}$ and $S P_{i}$ equal one if the security structure of transaction $i$ is a traditional or a structured PIPE, respectively. The indicator variable $H F_{i}$ equals one if hedge funds account for more than 50 percent of the total proceeds of the transaction. The observations where the identities of the majority of the investors are unknown are excluded. $X_{i}$ is a vector of additional accounting variables, year, and sector controls. The coefficient $\beta_{1}$ measures the marginal impact of issuances of structured relative to traditional PIPEs. The coefficients $\beta_{2}$ and $\beta_{3}$ indicate whether deals with hedge fund investors perform differently from deals with other investor classes for traditional and structured PIPEs, respectively.

We estimate two specifications using different time horizons: The first specification estimates equity performance controlling for the security structure and the investor composition. The second specification includes additional lagged accounting variables as controls. The number of observations is smaller in the second specification since we are unable to match all companies with valid stock return data to Compustat. All accounting variables are winsorized at the 1 percent level to eliminate the impact of extreme outliers. The standard errors are robust and corrected for clustering of observations by the same company.

Table 7 summarizes the regression results. The regressions also include additional year and industry fixed effects, which are not reported. The first column summarizes the results over the 10-day event window using the first specification. We find that companies issuing structured 
PIPEs perform substantially worse during the 10 days around the PIPE issuance than companies issuing traditional PIPEs. Moreover, the results indicate that companies receiving funding from hedge funds perform worse than companies receiving funding from other investor classes, although the coefficient on the interaction term for structured PIPEs and hedge fund investors is not statistically significant.

The second column adds control variables for the characteristics of the issuing company. These additional control variables do not significantly affect the estimated impact of the security structure and the investor composition on the short-term returns.

The remaining columns summarize the regression results using the long-term excess returns over two different time periods $([6,250]$, and $[6,500])$ as the dependent variables. The indicator variable for structured PIPEs enters significantly and confirms the previous results. Moreover, companies that issue traditional PIPEs and receive funding from hedge funds tend to underperform companies that receive funding from other investor classes. These results are highly statistically significant. On the other hand, companies that issue structured PIPEs and receive funding from hedge funds do not perform significantly different from companies that receive funding for structured PIPEs from other investor classes.

These results are not affected substantially if we control for additional variables. Companies with larger market capitalization experience larger underperformance than smaller companies. An important determinant of stock price performance is the indicator variable for whether a company recently received venture capital funding. Brav and Gompers (1997) show that venture capital backing adds value even after the initial public offering: venture-backed companies substantially outperform non-venture-backed firms in the public aftermarket. We confirm this result using PIPE companies. Companies that are venture-backed outperform companies that are not venture-backed by a substantial margin.

By controlling for the investor composition, security structure, and accounting characteristics, we are able to partially resolve the puzzle originally raised by Hertzel et al. (2002) of the contradiction between short-term gains of a private placements followed by longterm losses. We find that negative returns (short- and long-term) are primarily associated with companies issuing structured PIPEs and companies with hedge fund investors, companies which experience less pronounced short-term appreciations. 


\section{Calendar Time Portfolios}

In this section, we compute calendar-time abnormal returns of companies that issue PIPEs. Fama (1998) and Mitchell and Stafford (2000) argue that the event study methodology does not appropriately take into account cross-sectional dependencies in returns. To address this issue, we estimate abnormal returns based on the calendar-time portfolio approach by Mitchell and Stafford (2000).

\subsection{Calendar Time Portfolios: Methodology}

In a first step, we form a buy-and-hold portfolio of all the common stocks of companies that issue PIPEs during the past 500 trading days between 1996 and 2002. ${ }^{22}$ In a second step, we compute the abnormal returns using various factor models. The equally weighted portfolio invests $\$ 1$ in each PIPE issuing company the day after the close of the PIPE transaction. The portfolio holds each position for 500 days.

Due to the low liquidity in some of the companies issuing PIPEs, daily closing prices often are stale. Therefore, we analyze the weekly instead of daily returns for the calendar time portfolios. In addition, we include lagged factor returns to control for the staleness of equity prices. ${ }^{23}$ We compute abnormal returns using different factor models. The basic factor model has the following specification:

$$
R_{i, t}-R_{F, t}=\alpha_{i}+\sum_{k=1}^{K} \beta_{i}^{k} F_{t}^{k}+\sum_{k=1}^{K} \gamma_{i}^{k} F_{t-1}^{k}+e_{i, t},
$$

The dependent variable is the return on portfolio $i$ on day $t, R_{i, t}$, minus the risk-free rate, $R_{F, t}$. The $k$-th risk factor shock at time $t$ is denoted by $F_{t}^{k}$ and the contemporaneous and lagged factor loadings are given by $\beta_{i}^{k}$ and $\gamma_{i}^{k}$. The abnormal performance of the portfolio is measured by $\alpha_{i}$. The first model simply computes the average excess return relative to the market return. The second model estimates the abnormal return using the one-factor CAPM. The third model follows Fama and French (1993) and includes a market, a size, and a book-to-market factor. The

\footnotetext{
22 The results are consistent if we only include companies which issued PIPEs in the last 100 or 250 trading days.

${ }^{23}$ We obtain similar results if we use daily returns and if we do not include the lagged factor returns. Actually, the standard errors tend to be lower with daily returns because of the larger sample size.
} 
fourth model adds a momentum factor following Jegadeesh and Titman (1993) and Carhart (1997). ${ }^{24}$

Ferson and Schadt (1996) argue that unconditional measures of abnormal performance might be unreliable, because common variation in risk levels and risk premia will be confounded with average performance. They argue that a managed portfolio strategy that can be replicated using readily available public information should not be judged as having superior performance and advocate a model based on conditional performance, which uses predetermined instruments to capture the time-varying factor loadings. Our specification includes interaction terms between the Carhart factor returns and various demeaned macro-economic variables:

$$
R_{i, t}-R_{F, t}=\alpha_{i}+\sum_{k=1}^{K}\left(\beta_{i}^{k, 0}+\sum_{j=1}^{J} \beta_{i}^{k, j} z_{t-1}^{j}\right) F_{t}^{k}+\sum_{k=1}^{K}\left(\gamma_{i}^{k, 0}+\sum_{j=1}^{J} \gamma_{i}^{k, j} z_{t-1}^{j}\right) F_{t-1}^{k}+e_{i, t},
$$

where $z_{t-1}^{j}$ is the demeaned value of the lagged macro-economic variable $j$. Consistent with Ferson and Schadt (1996), we consider the following five variables: the one-month Treasury bill yield, the dividend yield of the CRSP value-weighted index, the Treasury yield spread (10-year minus 1-year Treasury bond yields), the quality spread in the corporate bond market (AAA minus BAA corporate bond yields), and an indicator variable for January. ${ }^{25}$ Our specification uses the four Carhart factors. However, we obtain similar results if we use a one- or a three-factor model.

Eckbo, Masulis, and Norli (2000) show that equity issuances lower the leverage of companies and increase the liquidity of the stocks of the issuing companies. They argue that this affects the exposure of companies to unexpected inflation and default risks, thus decreasing their stock's expected returns relative to matched firms. We also estimate their factor model that includes six macro factors: the value-weighted market index, the return spread between Treasury bonds with 10-year and 1-year maturities, the return spread between 90- and 30-day Treasury bills, the seasonally adjusted percent change in real per capita consumption of nondurable goods,

\footnotetext{
24 The daily factor returns for the three-factor model are obtained from Kenneth French's Web site: http://mba.tuck.dartmouth.edu/pages/faculty/ken.french/Data_Library. The daily momentum return is constructed following the description on French's Web site.

${ }^{25}$ The Treasury and corporate bond yields are obtained from the Web site of the Board of Governors of the Federal Reserve System: http://www.federalreserve.gov/releases/. The dividend yield and the Treasury bill yields are obtained from CRSP.
} 
the difference in the monthly yield change on BAA and AAA-rated corporate bonds, and unexpected inflation. ${ }^{26}$

\subsection{Calendar Time Portfolios: Results}

Table 8 summarizes the annualized abnormal returns for various portfolios of PIPE issuing companies, according to the security structure and the investor composition. The first row shows that a portfolio including all the stocks that issued PIPEs during the previous year has an average annualized excess return above the market of -18.49 percent per year. The calendar time portfolios confirm our previous results that companies issuing structured PIPEs and companies raising capital from hedge fund investors perform poorly. For example, portfolios including all companies that issue structured PIPEs during the previous two years experience abnormal returns between -31.08 and -39.98 percent using the different models. These abnormal returns are economically and statistically highly significant.

We also find the abnormal returns of the portfolios of companies selling equity to hedge funds are more negative than the portfolios of companies selling equity to other known investor classes for both security structures.

Companies issuing traditional PIPEs to non-hedge investors always have negative abnormal returns. However, the alphas are never significantly different from zero at conventional significance levels. Generally, the annualized abnormal returns are not very sensitive to the different factor models and tend to be larger if we have a longer portfolio inclusion window.

The results using calendar-time portfolios confirm the results using the event-study methodology. Thus, our results are not driven primarily by common variation in risk levels and risk premia or by changes of the fundamentals of the companies which result from equity issuances.

\footnotetext{
${ }^{26}$ We regress the daily portfolio returns on the original raw factor series, as reported in Panel D from Table 9 of Eckbo, Masulis, and Norli (2000). The Treasury and corporate bond yields are obtained from the Web site of the Board of Governors of the Federal Reserve System: http://www.federalreserve.gov/releases/. The Treasury bill yields are obtained from CRSP. Per capita non-durable consumption is obtained from the NIPA accounts of the Bureau of Economic Analysis (http://www.bea.doc.gov), and the consumer price inflation is obtained from the Bureau of Labor Statistics (http://www.bls.gov/cpi/). The estimation of expected inflation follows Eckbo, Masulis, and Norli (2000) by running a regression of real T-bill returns on a constant and 12 of its lagged values.
} 


\section{Accounting Performance}

This section studies whether the long-term stock price performance of PIPE issuing companies is generally consistent with the accounting performance. In particular, we analyze whether there is some association between security structure and investor composition with the long-term accounting performance.

\subsection{Event Study of Accounting Variables}

Table 9 reports three accounting variables: the return on assets, the book-to-market ratio, and the capital and research and development expenditures relative to the total assets for companies issuing PIPEs during a four-year window around the PIPE issuance. We find that companies issuing PIPEs continue to perform relatively poorly. While the ROA of companies issuing PIPEs to non-hedge funds improves from -36.3 to -26.2 percent, the ROA of companies issuing PIPEs to hedge funds actually worsens from -39.7 to -42.9 percent in the second fiscal year following the PIPE issue. Companies that issue structured PIPEs continue to perform significantly worse than companies that issue traditional PIPEs during the two fiscal years following the PIPE issue.

Panel B shows that PIPE companies resemble value companies more after the PIPE transactions, as compared to before, reflecting primarily a deterioration of market valuations. Panel C indicates that the median PIPE company reduces its capital, research, and development expenditures in the years after the close of the PIPE, suggesting that the capital raised through PIPE transactions does not allow companies to permanently maintain or increase their real investment activities. These persistently poor accounting results support our earlier assertion that PIPE investors do not actively monitor their companies, as discussed by Barclay, Holderness, and Sheehan (2003) and $\mathrm{Wu}(2004)$.

\subsection{Regression Evidence}

Table 10 summarizes the determinants of the accounting performance after the issuance of PIPE securities. The dependent variable is the return of assets during the first fiscal year after the PIPE issuance (column 1) and during the second fiscal year after the PIPE issuance (column 2). The dependent variable is winsorized at the 1 percent level to eliminate the effect of a small number of outliers. The return on assets is regressed on the PIPE structure and the interaction 
effects between traditional and structured PIPEs and hedge fund investors. In addition, we include the accounting variables discussed previously as well as year and sector fixed effects. The accounting variables also include the return on assets during the fiscal year prior to the PIPE issuance as a control variable. ${ }^{27}$

The results indicate that companies issuing structured PIPEs tend to experience worse operating performance than traditional PIPEs after the PIPE issuance, although the results are not highly statistically significant. We must interpret these results with caution since these regressions only use the surviving companies; accounting data are unavailable for companies that are delisted from major exchanges. In our sample, companies that issue structured PIPEs are considerably more likely to be delisted than companies that issue traditional PIPEs. For example, in the two years following the PIPE issuance, 35.8 percent of structured and 26.6 percent of traditional PIPEs are delisted. The vast majority of these delistings occur because the stocks are delisted by NASDAQ, NYSE, or AMEX for not satisfying the listing requirements. Thus, companies that issue structured PIPEs are more likely to be delisted; and if they continue to be listed, then they continue to have worse operating performance. ${ }^{28}$

There is also some evidence that companies that are associated with hedge fund investors experience worse operating performance. In addition, companies receiving funding from hedge funds are also more likely to be delisted within two years of the PIPE issuance. For example, in the two years following the PIPE issuance, 34.6 percent of companies receiving funding from hedge funds and 25.6 percent of companies receiving funding from other known investors are delisted.

The additional control variables are able to explain a relatively large fraction of the variation in the return in assets. The lagged return on assets is particularly important because it is highly auto-correlated. Moreover, larger firms, growth firms, and firms with positive stock price momentum tend to experience superior long-term operating performance.

\section{Short Interest of PIPE Issuing Companies}

Our results indicate that the structure and identity of the investor matters for the short and long-term stock price and accounting performance of companies issuing PIPEs. Companies

\footnotetext{
${ }^{27}$ Chou, Gombola, and Liu (2004) do not find significant earnings management for private placements of equity.
} 
issuing structured PIPEs and companies obtaining financing from hedge funds tend to perform significantly worse than comparable companies. The interesting question to be considered is the causal link between structure, investor, and performance.

Hillion and Vermaelen (2004) suggest that a structured PIPE might be a faulty contract due to the incentives for investors to manipulate the price downward to receive a higher percentage of the firm upon conversion. Our finding of a negative association between structured PIPEs purchased by hedge funds and long-term performance is consistent with their hypothesis. We also find that while the number of traditional PIPE issuances increases in our sample, the number of structured PIPEs decreases - a fact that could be explained as firms learning and subsequently avoiding issuing these flawed securities.

To better understand the cause of this negative long-term performance by firms that issue convertible PIPEs we explore the short interest market. We compute the average ratio between securities shorted and the total number of securities outstanding for firms surrounding the PIPE transaction date. We repeat this procedure for a matched firm (with matching based on industry, size, book-to-market, and momentum) and report the difference as "abnormal" shorting.

Figure 3 reports the abnormal short interest of companies issuing traditional and structured PIPEs for hedge and non-hedge investors. We find that traditional PIPE companies that obtain financing from hedge funds have higher initial levels and larger increases in the short interest around PIPE issuances. This result is consistent with the observation that some hedge funds eliminate their risk exposure after investments in PIPE securities by taking short positions in the underlying stocks. ${ }^{29}$ We also find that the short interest decreases gradually within the first two years after the PIPE issuances. This result is consistent with hedge funds closing out their short positions as the lock-up periods expire and disposing of their original PIPE purchase.

For structured PIPEs, we find that the short interest increases for transactions done by both hedge and non-hedge fund investors. We do not find a statistically significant difference between the short interest changes for hedge and non-hedge investors. Moreover, we do not find a significant difference in the changes in short interest for companies issuing traditional and structured PIPEs to hedge funds. If the short selling is motivated by the ability to manipulate the

\footnotetext{
${ }^{28}$ This survivorship bias does not affect our stock return performance results to a similar degree since we included also delisted companies in our analysis.
} 
underlying security to receive a more favorable conversion ratio, we should expect to see a substantially larger increase in short interest in companies obtaining hedge fund investments through structured PIPEs. Actually, the increase in short interest is less pronounced for companies issuing structured PIPEs to hedge funds than for companies issuing traditional PIPEs to hedge funds. ${ }^{30}$

Though short sales are specified in the original faulty contract hypothesis of Hillion and Vermaelen (2004), shorting is but one of several ways hedge funds could manipulate the underlying equity and we can not rule out all possible methods of manipulating stock prices. However, we find that hedge funds tend to invest in firms with higher pre-issuance trading volume and short interest (see Table 3). Hedge funds are technical investors interested in trading liquid securities and they choose to invest in companies with high trading volumes and that can be short-sold easily. These results cast doubt on the hypothesis that hedge fund investors systematically seek companies whose prices can be more easily manipulated, since companies with low trading volume and with a non-existent short-selling market might be more susceptible to market manipulation.

\section{Conclusions}

This paper discusses the short- and long-term performance of companies issuing equity privately. We show that, on average, these companies under-perform comparable firms in the two years following the closing of the PIPE transactions. We find that both the structure of the PIPE and the investor composition in the PIPE matter in understanding why firms issue the security and the subsequent performance of the issuing firm. Poor post-issuance performance is associated with structured PIPEs, where investors obtain significant repricing rights, and with hedge fund investors.

We find that firms in our sample have significant need for external capital because of poor operating performance and large capital, research, and development expenses. There is also evidence indicating these firms have limited financing options complicated by high degrees of

\footnotetext{
${ }^{29}$ The increase in short interest is considerably more pronounced for issuances of common stock PIPEs than for issuances of fixed convertibles, since fixed convertibles partially protect against price declines in the stock of the underlying company.

${ }^{30}$ The increase in the short interest for structured PIPEs either could result from the desire of investors to hedge their exposure to the company or from other unrelated investors that perceive the announcement of a structured PIPE
} 
asymmetric information. These results support our earlier assertion that firms are motivated to issue PIPEs to minimize the asymmetric information costs associated with issuing external finance.

We find little to no abnormal performance in firms issuing traditional PIPEs sold to nonhedge fund investors. However, we find significant abnormal performance if the equity security is bought by a hedge fund. We also report that companies issuing traditional PIPEs bought by hedge funds tend to have more negative accounting characteristics in the year preceding issuance and that these characteristics are weakly associated with negative long-run returns. These results are consistent with the hypothesis that hedge funds act as investors of last resort, playing an important role in the market for young, high-risk firms with substantial asymmetric information and large capital needs. However, we do not find direct evidence that the dismal performance of companies obtaining financing through structured PIPEs is caused by market manipulation.

as negative news. Investors in structured PIPEs still might want to take a short position in the underlying stock because the variable conversion ratio does not provide protection in the case of default. 


\section{Appendix A: Security Structure}

\section{A.1. Common Stock PIPEs}

The most basic PIPE security is a common stock placement, where a fixed number of shares are issued and sold at a predetermined discount or premium to the market price. Common stock PIPEs sometimes include warrants that let the investor purchase additional shares at a predetermined price during a specific time period.

\section{A.2. Common Stock PIPEs - Shelf Sale}

A small number of PIPEs are shelf sales of common stocks, which are sales of a company's common stock from an existing shelf registration statement. The registration allows the company to sell the securities over a period of time.

\section{A.3. Fixed Convertible PIPEs}

Fixed convertible PIPEs are either specified as convertible preferred stock or convertible debt. Preferred stock represents equity ownership that is ranked higher than common stock in case of bankruptcy or liquidation. Convertible debt is a loan obligation of the company that ranks higher than any equity securities. Fixed convertibles yield a current return through interest or dividend payments and can be converted by the investors into a fixed number of shares of the company's common stock at a predetermined ratio. The implied fixed conversion price is usually above the current market price. Investors in fixed convertibles exchange their securities for common stocks if the stock price is sufficiently high on the conversion date.

\section{A.4. Floating Convertible PIPEs}

Floating convertibles have a variable conversion price that is based on future market prices of the common stock after the issuance but before the time of conversion. This feature protects the investor if the price of the common stock changes after the PIPE deal is closed, because the investor will receive increasing numbers of shares if stock prices decrease. Floating convertible PIPEs are either specified as convertible preferred stock or convertible debt. Floating convertibles often include caps and floors which limit the possible range of conversion prices. 


\section{A.5. Reset Convertible PIPEs}

Reset convertibles have a fixed conversion price that is subject to a number of resets at specific times following the closing date. At the time of each of the resets, the fixed conversion

price is adjusted as a percentage of the current market price and then remains fixed at this new price until the next reset date.

\section{A.6. Common Stock Reset PIPEs}

A small number of common stock private placements are classified as common stock resets. These deals include repricing rights, which allow the investor to receive additional shares of common stocks if the market price decreases after the closing date. The repricing rights clause functions very similarly to a floating convertible in that the number of issuable shares can change every day. Additionally, there may be a limit on the number of shares which are issued pursuant to the repricing rights.

\section{A.7. Structured Equity Line PIPEs}

A structured equity line is an agreement that requires the investor to purchase a predetermined value of the company's common stock over a certain period of time. The price of the stock is usually determined as an average of the closing price during a pre-specified period in the future minus a fixed discount.

\section{A.8. Performance by Detailed Security Structure}

In Table 11, we subdivide the PIPEs according to more detailed specifications of the securities issued and compute the abnormal returns. Panel A shows that common stock PIPEs are the dominant security in the traditional PIPEs market. Fixed convertible preferred stock and fixed convertible debt also account for a significant share of transactions. Panel B lists six different security structures that are included as structured PIPEs.

The short- and long-term performance of the underlying common stocks after the PIPE issuance for the detailed security structures does not differ significantly within the two basic security structures. The companies issuing any of the six different variable convertible structures perform very poorly relative to their matched companies and relative to companies that issue common stock or fixed convertible PIPEs. 


\section{Appendix B: Estimation Methodology}

This section explains the methodology used to perform the event study in Section 4. First, we download at the end of each calendar year from CRSP the SIC codes and the market capitalizations of all the common stocks that are not closed-end funds, ADRs, REITs, and that are headquartered in the U.S. We merge this data set with the corresponding book-to-market ratios from Compustat. For companies with fiscal year-ends before October, we use the book value at the end of the current fiscal year and for companies with fiscal year-ends after September, we use the book values at the end of the previous fiscal year. Thus, the book values at the end of each calendar year are lagged by at least three months to allow some time delay for the publication of the accounting values after the end of the fiscal year.

Second, we match companies according to their industry classification, size, book-tomarket ratio, and momentum. We classify all the companies into 48 industries according to the SIC codes, as described in Fama and French (1997). ${ }^{31}$ We rank the companies in each of these 48 industries by their market capitalization, their book-to-market ratio, and their return during the previous 12 months. At the end of each month, we match each company to another company in the same industry that did not issue a PIPE in the previous two years such that the sum of the absolute deviations of the size, the book-to-market, and the momentum rankings is smallest. If either the size, book-to-market ratio, or momentum returns are missing, then we match the company to another company in the same industry group with missing size, book-to-market ratio, or momentum returns. The distribution of the characteristics for the PIPE and the comparable companies is very close. ${ }^{32}$

When we match firms by industry, age, size, book-to-market ratio, and momentum, we first choose all the companies in one of the same of 10 industries, according to the industry grouping in Kacperczyk, Sialm, and Zheng (2004). Subsequently, we select companies that fall in the same age range: 0-6 months; 7-12 months; 13-24 months; 25-36 months; 37-60 months; 60-120 months; 121-240 months; and above 241 months. To select a unique matching firm from

\footnotetext{
${ }^{31}$ The industry classification can be obtained from Kenneth French's Web site: http://mba.tuck.dartmouth.edu/pages/faculty/ken.french/Data_Library.

32 For example, companies issuing PIPEs have a median size of $\$ 64.7$ million, a median book-to-market ratio of 0.20 , and median past-year returns of -15.0 percent. Companies matched according to industry, size, book-to-market ratio, and momentum have a median size of $\$ 62.2$ million, a median book-to-market ratio of 0.24 , and median pastyear returns of -15.4 percent. The companies also match well with respect to other relevant characteristics that were not matched. For example, the median age of a PIPE company is 4.6 years, while the median age of the matched company is 5.2 years. 84.3 percent of PIPE companies and 78.4 percent of matched companies trade on NASDAQ.
} 
these companies in the same industry and in the same age range, we rank them according to size, book-to-market, and momentum, as described in the Appendix.

Third, we compute the daily buy-and-hold returns for all companies in our sample during a 1,000-trading-day window around the closing date of the PIPE transaction. If the returns for a company that issues a PIPE are not available in CRSP, we set the returns equal to the returns of the matched company. If the returns of the comparable company are not available, then we set the returns equal to the value-weighted index. This avoids the introduction of a delisting bias, because companies that are delisted perform, on average, poorly before delisting. ${ }^{33}$ If the holding period returns for a matched company are not available in CRSP, then we replace this company with the company that had the next-closest match at the end of the calendar year prior to the closing date of the PIPE.

Fourth, we compare these average returns for different PIPE deals over various sample periods. The abnormal return is defined as the difference between the buy-and-hold return of the PIPE company and the buy-and-hold return of the matched company.

\section{Appendix C: Bootstrap Simulations}

To check the robustness of our significance levels, we run bootstrap simulations using the pseudo-portfolio approach from Lyon, Barber, and Tsai (1999). ${ }^{34}$ For each PIPE firm, we randomly select with replacement on the event day a firm that is in the same size and book-tomarket portfolio.

All domestic ordinary common stocks are first sorted into deciles according to the market capitalization of companies listed on the NYSE. Subsequently, we divide up the smallest decile into quintiles. Thus, we obtain 14 size portfolios. Each size portfolio is further divided into quintile portfolios according to the book-to-market ratios. Companies that have missing book-tomarket values in Compustat are matched to companies with missing book-to-market values. The portfolios are formed at the end of each month.

If a company issues multiple PIPEs during our sample period, we match all these observations to the same replacement firm to take into account possible clustering by firms.

\footnotetext{
${ }^{33}$ A relatively large number of our PIPE companies are delisted during the two years after the closing of the PIPE. For example, 8.5 percent of the companies delist within the first year after the PIPE security is issued.

${ }^{34}$ Similar methods were developed by Brock, Lakonishok, and LeBaron (1992), Ikenberry, Lakonishok, and Vermaelen (1995), and Lee (1997), among others.
} 
Subsequently, we estimate the abnormal performance of the randomly selected firms as was done for the original sample. We repeat this process 1,000 times and derive 1,000 mean abnormal return observations. These observations are used to approximate the empirical distribution of mean long-run abnormal returns.

We generally obtain the same levels of statistical significance as using conventional $t$ tests. For example, the simulated short-term abnormal return during a 10-day trading window using all PIPE issuances has a standard deviation of 0.44 percent compared to the 0.53 percent listed in the first column of Table 4. Moreover, none of the 1,000 simulations result in abnormal returns above 3.87 percent, indicating that our results are highly statistically significant using the bootstrap simulations.

We also obtain similar significance levels for the long-term returns for the two security types: The standard deviations of the two-year abnormal returns are 4.16 percent for traditional and 6.86 percent for structured PIPEs, which are very similar to the standard errors reported in Table 4. We find that none of the bootstrap simulations give a lower long-term abnormal return than -13.03 percent for traditional PIPE companies. Moreover, none of the simulations are even close to the dismal performance of variable convertible PIPEs of -38.83 percent during the two years following the PIPE transaction. The worst of 1,000 simulations gives an abnormal return of -24.42 percent. This indicates that the poor performance of companies issuing PIPEs, in general, and companies issuing structured PIPEs, in particular, is very unlikely to be driven by chance alone.

\section{Appendix D: Compustat Data Definitions}

The Compustat data items to calculate the ratios, total assets (item 6), market-adjusted leverage (book debt (total liabilities (item 181) + preferred stock liquidating value (item 10, if unavailable, preferred stock redemption value (item 56)) - deferred taxes (item 35) - convertible debt (item 79))/(book debt + market capitalization)), book to market (book equity (item $60) /($ common shares used to calculate EPS (item 54) * fiscal year close price (item 199))), return on equity (income before extraordinary items (item 237)/book equity (item 60)), operating profit (operating income before depreciation (item 13)), capital expenditures \& research and development/total assets (capital expenditures (item 128) + research and development expense (item 46)/total assets (item 6)). 


\section{References}

Aboody, David and Baruch Lev (2000): “Information Asymmetry, R\&D and Insider Gains.” Journal of Finance 55, 2747-2766.

Ackermann, Carl, Richard McEnally and David Ravenscraft (1999): "The Performance of Hedge Funds: Risk, Return and Incentives.” Journal of Finance 54, 833-874.

Asquith, Paul and David W. Mullins (1986): “Equity Issues and Offering Dilution.” Journal of Financial Economics 15, 61-89.

Ball, Ray, S. P. Kothari, and Jay Shanken (1995): "Problems in Measuring Portfolio Performance: An Application to Contrarian Investment Strategies.” Journal of Financial Economics 38, 79-107.

Barber, Brad M. and John D. Lyon (1997): “Detecting Long-Run Abnormal Stock Returns: The Empirical Power and Specification of Test Statistics.” Journal of Financial Economics 43, 341-372.

Barclay, Michael J., Clifford G. Holderness, and Dennis P. Sheehan (2003): "Private Placements and Managerial Entrenchment.” Unpublished Manuscript.

Booth, James R. and Richard L. Smith (1986): "Capital Raising, Underwriting and the Certification Hypothesis.” Journal of Financial Economics 15, 261-281.

Brav, Alon and Paul A. Gompers (1997): "Myth or Reality? The Long-Run Underperformance of Initial Public Offerings: Evidence from Venture and Nonventure Capital-Backed Companies.” Journal of Finance 52, 57-82.

Brennan, Michael J. and Avanidhar Subrahmanyam (1995): "Investment Analysis and Price Formation in Securities Markets” Journal of Financial Economics 38, 361-381.

Brock, William, Josef Lakonishok, and Blake LeBaron (1992): "Simple Technical Trading Rules and the Stochastic Properties of Stock Returns.” Journal of Finance 47, 1731-1764.

Carhart, Mark M (1997): “On Persistence in Mutual Fund Performance.” Journal of Finance 52, 57-82.

Chemmanur, Thomas J. and Paolo Fulghieri (1999): “A Theory of the Going-Public Decision.” Review of Financial Studies 12, 249-279.

Chou, De-Wai, Michael Gombola, and Feng-Ying Liu (2004): "Earnings Management and the Underperformance of Private Placements of Equity.” Working Paper, Drexel University.

Cornett, Marcia M. and Hassan Tehranian (1994): “An Examination of Voluntary versus Involuntary Security Issuances by Commercial Banks.” Journal of Financial Economics 35, 99-122.

Diether, Karl, Christopher Malloy, and Anna Scherbina (2002): "Differences of Opinion and the Cross-Section of Stock Returns.” Journal of Finance 57, 2113-2141.

Eckbo, B. Espen, Ronald W. Masulis, and Oyvind Norli (2000): “Seasoned Public Offerings: Resolution of the 'New Issues Puzzle'.” Journal of Financial Economics 56, 251-291. 
Fama, Eugene (1998): “Market Efficiency, Long-Term Returns, and Behavioral Finance.” Journal of Financial Economics 49, 283-306.

Fama, Eugene F., and Kenneth R. French (1992): "The Cross-Section of Expected Stock Returns.” Journal of Finance 47, 427-465.

Fama, Eugene F., and Kenneth R. French (1993): "Common Risk Factors in the Return on Bonds and Stocks.” Journal of Financial Economics 33, 3-53.

Fama, Eugene F., and Kenneth French (1997): "Industry Costs of Equity.” Journal of Financial Economics 43, 153-193.

Ferson, Wayne E. and Rudi W. Schadt (1996): "Measuring Fund Strategy and Performance in Changing Economic Conditions.” Journal of Finance 51, 425-461.

Fields, L. Paige and Eric L. Mais (1991): “The Valuation Effect of Private Placements of Corporate Debt.” Journal of Finance 46, 1925-1932.

Gomes, Armando and Gordon Phillips (2004): "Why Do Public Firms Issue Private and Public Equity, Convertibles and Debt?” University of Pennsylvania Working Paper.

Habib, Michel A. and D. Bruce Johnsen (2000): “The Private Placement of Debt and Outside Equity as an Information Revelation Mechanism.” Review of Financial Studies 13, 10171055.

Hertzel, Michael and Richard L. Smith (1993): "Market Discounts and Shareholder Gains for Placing Equity Privately.” Journal of Finance 48, 459-485.

Hertzel, Michael, Michael Lemmon, James S. Linck, and Lynn Rees (2002): "Long-run Performance Following Private Placements of Equity.” Journal of Finance 59, 25952617.

Hillion, Pierre and Theo Vermaelen (2004): “Death Spiral Convertibles.” Journal of Financial Economics 71, 381-415.

Ikenberry, David, Josef Lakonishok, and Theo Vermaelen (1995): "Market Underreaction to Open Market Share Repurchases.” Journal of Financial Economics 39, 181-208.

Jegadeesh, Narasimhan, and Sheridan Titman (1993): "Returns to Buying Winners and Selling Losers: Implication for Stock Market Efficiency.” Journal of Finance 48, 65-91.

Kacperczyk, Marcin, Clemens Sialm, and Lu Zheng (2004): “On the Industry Concentration of Actively Managed Equity Mutual Funds.” Forthcoming: Journal of Finance.

Krishnamurthy, Srinivasan, Paul Spindt, Venkat Subramaniam, and Tracie Woidtke (2004): "Does Investor Identity Matter in Equity Issues? Evidence from Private Placements." Forthcoming: Journal of Financial Intermediation

Lee, Inmoo (1997): “Do Firms Knowingly Sell Overvalued Equity?” Journal of Finance 52, 1439-1466.

Loughran, Tim and Jay R. Ritter (1995): “The New Issues Puzzle.” Journal of Finance 50, 2351. 
Loughran, Tim and Jay R. Ritter (1997): “The Operating Performance of Firms Conducting Seasoned Equity Offerings.” Journal of Finance 52, 1823-1850.

Lyon, John D., Brad M. Barber, and Chih-Ling Tsai (1999): “Improved Methods for Tests of Long-Run Abnormal Returns.” Journal of Finance 54, 165-201.

Masulis, Ronald W. and Ashok N. Korwar (1986): "Seasoned Equity Offerings: An Empirical Investigation.” Journal of Financial Economics 15, 91-118.

Mikkelson, Wayne and Megan Partch (1986): "Valuation Effects of Security Offerings and the Issuance Process.” Journal of Financial Economics 15, 31-60.

Mitchell, Mark L. and Erik Stafford (2000): “Managerial Decisions and Long-Run Stock Price Performance.” Journal of Business 73, 287-320.

Myers, Stewart C (1984): “The Capital Structure Puzzle.” Journal of Finance 39, 575-592.

Myers, Stewart C. and Nicholas S. Majluf (1984): "Corporate Financing and Investment Decisions When Firms Have Information That Investors Do Not Have.” Journal of Financial Economics 13, 187-221.

Ritter, Jay (1991): “The Long-Run Performance of Initial Public Offerings.” Journal of Finance 46, 3-27.

Shyam-Sunder, Lakshmi (1991): “The Stock Price Effect of Risky versus Safe Debt.” Journal of Financial and Quantitative Analysis 26, 549-558.

Silber, William L. (1991): "Discounts on Restricted Stock: The Impact of Illiquidity on Stock Prices.” Financial Analysts Journal 47, 60-64.

Smith, Clifford W. (1986): "Investment Banking and the Capital Acquisition Process.” Journal of Financial Economics 15, 3-29.

Stein, Jeremy (1992): “Convertible Bonds as 'Backdoor' Equity Financing.” Journal of Financial Economics 32, 3-22.

Spiess, D. Katherine and John Affleck-Graves (1995): "Underperformance in Long-Run Stock Returns Following Seasoned Equity Offerings.” Journal of Financial Economics 38, 243267.

Varma, Raj and Samuel H. Szewczyk (1993): “The Private Placement of Bank Equity.” Journal of Banking and Finance 17, 1111-1131.

Wruck, Karen H. (1989): "Equity Ownership Concentration and Firm Value. Evidence from Private Equity Financings.” Journal of Financial Economics 23, 3-28.

Wu, Yi Lin (2004): “The Choice of Equity-Selling Mechanisms.” Journal of Financial Economics 74, 93-119. 
Table 1: Summary Statistics

This table summarizes the characteristics of PIPE transactions.

Panel A: Characteristics of PIPE Transactions

\begin{tabular}{lccc}
\hline & All & Traditional & Structured \\
& PIPEs & PIPEs & PIPEs \\
\hline Number of Transactions & 5,260 & 3,592 & 1,668 \\
Total Capital Raised (in Millions) & 76,743 & 64,985 & 11,758 \\
Mean Capital Raised (in Millions) & 14.66 & 18.19 & 7.05 \\
Median Capital Raised (in Millions) & 4.50 & 5.00 & 3.30 \\
Mean Market Value (in Millions) & 183.72 & 218.09 & 109.71 \\
Median Market Value (in Millions) & 50.09 & 53.05 & 43.74 \\
Mean Capital Raised to Market Value (in Percent) & 20.87 & 22.80 & 16.69 \\
Median Capital Raised to Market Value (in Percent) & 9.91 & 10.77 & 8.51 \\
Mean Number of Investors per Deal & 4.45 & 5.02 & 3.22 \\
Median Number of Investors per Deal & 1 & 2 & 1 \\
\hline
\end{tabular}

Panel B: Proportion of Capital Raised by Various Investor Classes (in Percent)

\begin{tabular}{lccc}
\hline & All & Traditional & Structured \\
& PIPEs & PIPEs & 71.72 \\
\hline Hedge Funds & 24.57 & 15.63 & 4.85 \\
Corporations & 17.23 & 19.58 & 2.55 \\
Mutual Funds and Institutional Advisors & 16.94 & 19.67 & 5.63 \\
Venture Capital & 11.76 & 12.92 & 0.69 \\
Buyout Firm and Private Equity & 11.51 & 13.56 & 4.53 \\
Various Individual Investors & 6.18 & 6.49 & 6.32 \\
Brokers and Dealers & 6.15 & 6.12 & 2.64 \\
Banks & 2.19 & 2.11 & 0.80 \\
Insurance Companies & 2.01 & 2.25 & 0.09 \\
Pension Funds & 0.90 & 1.06 & 0.18 \\
Charitable, Educational, and Family Trusts & 0.55 & 0.62 & \\
\hline & & & \\
Panel C: Proportion of Capital Raised by Industry Composition (in Percent) & & Traditional \\
\hline & All & PIPEs & PIPEs \\
\hline Communications & PIPEs & 37.47 & 35.46 \\
Healthcare & 37.16 & 19.86 & 22.13 \\
Consumer Cyclical & 20.20 & 6.03 \\
Technology & 9.79 & 10.46 & 7.27 \\
Industrial & 8.60 & 7.40 & 3.09 \\
Financial & 7.31 & 7.23 & 2.65 \\
Energy & 7.19 & 7.92 & 5.27 \\
Consumer Noncyclicals & 3.33 & 3.46 & 0.86 \\
Utilities & 2.83 & 2.39 & 1.21 \\
Basic Materials & 2.31 & 2.57 & 0.27 \\
Diversified & 1.18 & 1.18 &
\end{tabular}


Table 2: Characteristics of PIPE Companies

Panel A summarizes stock market measures of PIPE companies. Panel B compares the accounting ratios of PIPE companies using Compustat data. All reported accounting numbers are sampled from the preceding fiscal year-end report and are winsorized at the 1-percent level. We test for the differences between the characteristics of traditional and structured PIPEs using a standard $t$-test with for the means assuming unequal standard deviations and a nonparametric Fisher test for the medians. The significance levels are denoted by '*', '**', and '***' and indicate whether the results are statistically different from zero at the 10, 5, and 1 percent confidence levels.

Panel A: Stock Market Measures

\begin{tabular}{|c|c|c|c|c|c|}
\hline & & $\begin{array}{c}\text { All } \\
\text { PIPEs }\end{array}$ & $\begin{array}{c}\text { Traditional } \\
\text { PIPEs }\end{array}$ & $\begin{array}{l}\text { Structured } \\
\text { PIPEs }\end{array}$ & Difference \\
\hline Age (Years Since Listing on Major Stock & Mean & 6.9 & 7.1 & 6.6 & $-0.5 * *$ \\
\hline Exchange) & Median & 4.8 & 4.8 & 4.3 & $-0.5^{* * *}$ \\
\hline Market Capitalization & Mean & 183.7 & 218.1 & 109.7 & $-108.4^{* * *}$ \\
\hline (in Millions) & Median & 50.1 & 53.1 & 43.7 & $9.4 * * *$ \\
\hline Stock Returns in Year Before Close & Mean & 30.0 & 29.0 & 31.9 & -2.9 \\
\hline (in Percent) & Median & -17.8 & -15.4 & -21.7 & $-6.3 *$ \\
\hline Annualized Standard Deviation of Stock & Mean & 76.9 & 76.1 & 78.8 & 2.7 \\
\hline Returns in Year Before Close (in Percent) & Median & 67.7 & 68.7 & 67.2 & -1.5 \\
\hline Annualized Trading Volume By Total Shares & Mean & 230.1 & 203.8 & 289.0 & $85.2^{* * *}$ \\
\hline Six Months Before Close (in Percent) & Median & 122.2 & 106.8 & 163.3 & $56.5^{* * *}$ \\
\hline Short Positions By Total Shares Six Months & Mean & 2.2 & 2.1 & 2.5 & $0.4^{* * *}$ \\
\hline Before Close (in Percent) & Median & 0.6 & 0.5 & 0.8 & $0.3^{* * *}$ \\
\hline Number of Analysts & Mean & 1.1 & 1.3 & 0.7 & $-0.6^{* * *}$ \\
\hline Companies With Analyst Coverage (in Percent) & Proportion & 31.6 & 35.5 & 23.2 & $-12.3^{* * *}$ \\
\hline $\begin{array}{l}\text { Venture Capital-Backed for Companies with } \\
\text { IPOs in Prior Five Years (in Percent) }\end{array}$ & Proportion & 27.9 & 32.2 & 19.0 & $-13.2^{* * *}$ \\
\hline \multicolumn{6}{|l|}{ Panel B: Accounting Measures } \\
\hline & & $\begin{array}{c}\text { All } \\
\text { PIPEs }\end{array}$ & $\begin{array}{l}\text { Traditional } \\
\text { PIPEs }\end{array}$ & $\begin{array}{l}\text { Structured } \\
\text { PIPEs }\end{array}$ & Difference \\
\hline Return on Equity & Mean & -208.0 & -199.2 & -228.6 & -29.4 \\
\hline (in Percent) & Median & -62.7 & -58.7 & -76.0 & $-17.3 * * *$ \\
\hline Return on Assets & Mean & -64.1 & -62.8 & -67.1 & -4.3 \\
\hline (in Percent) & Median & -36.9 & -35.0 & -42.5 & $-7.5 * * *$ \\
\hline $\begin{array}{l}\text { Proportion of Firms with Positive } \\
\text { Return on Assets (in Percent) }\end{array}$ & & 15.1 & 17.1 & 10.4 & $-6.6 * * *$ \\
\hline Total Assets & Mean & 175.4 & 212.7 & 87.7 & $-125.1^{* * *}$ \\
\hline (in Million \$) & Median & 26.1 & 29.0 & 20.3 & $-8.7^{* * *}$ \\
\hline Book-to-Market Ratio & Mean & 42.3 & 47.3 & 30.4 & $-16.9 * * *$ \\
\hline (in Percent) & Median & 22.4 & 24.3 & 18.3 & $-6.0 * * *$ \\
\hline Capital Expenditures and R\&D Divided by & Mean & 32.0 & 32.3 & 31.1 & -1.2 \\
\hline Total Assets (in Percent) & Median & 21.0 & 21.2 & 20.7 & -0.5 \\
\hline Market-Adjusted Leverage & Mean & 25.8 & 27.7 & 21.4 & $-6.3^{* * *}$ \\
\hline (in Percent) & Median & 16.7 & 17.5 & 14.0 & $-3.5 * * *$ \\
\hline
\end{tabular}


Table 3: Determinants of Security Structure and Investor Compositions: Multinomial Logit Estimation

This table summarizes the estimates of a maximum-likelihood multinomial logit estimation. The dependent variable corresponds to the four combinations between security structure and investor composition: (1) traditional PIPEs and non-hedge fund investors; (2) traditional PIPEs and hedge fund investors; (3) structured PIPEs and non-hedge fund investors; and (4) structured PIPEs and hedge fund investors. The first group is taken as the comparison group. The multinomial logit estimation includes year- and sector-fixed effects that are not reported. The standard errors are robust, corrected for clustering of observations by the same company and are summarized in parentheses. The significance levels are denoted by '*', '**', and '***' and indicate whether the results are statistically different from zero at the 10, 5 , and 1 percent confidence levels.

\begin{tabular}{lccc}
\hline Explanatory Variables & $\begin{array}{l}\text { Traditional PIPE and } \\
\text { Hedge Investors } \\
\text { Compared to } \\
\text { Traditional PIPE and } \\
\text { Non-Hedge Investors }\end{array}$ & $\begin{array}{l}\text { Structured PIPE and } \\
\text { Non-Hedge Investors } \\
\text { Compared to } \\
\text { Traditional PIPE and } \\
\text { Non-Hedge Investors }\end{array}$ & $\begin{array}{l}\text { Structured PIPE and } \\
\text { Hedge Investors } \\
\text { Compared to } \\
\text { Traditional PIPE and } \\
\text { Non-Hedge Investors }\end{array}$ \\
\hline Log of Market Value at & 0.005 & -0.085 & $-0.199^{* * *}$ \\
Close & $(0.062)$ & $(0.094)$ & $(0.068)$ \\
Book-to-Market Ratio at & $-0.331^{* * *}$ & $-0.420^{*}$ & -0.196 \\
Fiscal Year Prior to Close & $(0.124)$ & $(0.247)$ & $(0.150)$ \\
Excess Return During Two & 0.000 & -0.088 & -0.024 \\
Years Prior to Close & $(0.019)$ & $(0.061)$ & $(0.036)$ \\
Log of Trading Volume & $0.246^{* * *}$ & $0.139^{*}$ & $0.422^{* * *}$ \\
Six Months Prior to Close & $(0.053)$ & $(0.073)$ & $(0.059)$ \\
Short Interest Six Months & 1.302 & 2.500 & $2.985^{*}$ \\
Prior to Close & $(1.524)$ & $(2.057)$ & $(1.692)$ \\
Venture Capital Funded & -0.216 & $-0.612^{* * *}$ & $-0.507^{* * *}$ \\
During Prior Five Years & $(0.151)$ & $(0.214)$ & $(0.154)$ \\
Return of Assets at Fiscal & 0.051 & -0.108 & -0.022 \\
Year Prior to Close & $(0.091)$ & $(0.114)$ & $(0.093)$ \\
Market Leverage at Fiscal & -0.093 & -0.195 & $-0.249^{*}$ \\
Year Prior to Close & $(0.138)$ & $(0.168)$ & $(0.133)$ \\
Number of Analysts & $-0.080^{* * *}$ & -0.036 & $-0.093^{* * *}$ \\
& $(0.026)$ & $(0.046)$ & $(0.028)$ \\
\hline Pseudo R-Squared & 0.1145 & & \\
Number of Observations & 2,419 & & \\
& & & \\
\hline
\end{tabular}


Table 4: Abnormal Returns to Common Stocks of Companies that Issue PIPEs

This table summarizes the mean abnormal returns of the common stocks of companies issuing PIPEs. The benchmark returns are companies matched in the month prior to the PIPE deal according to industry, size, book-tomarket ratio, and momentum. The returns are expressed in percent. The standard errors for the means are reported in parentheses. The significance levels are denoted by '*', '**', and '***' and indicate whether the results are statistically different from zero at the 10,5 , and 1 percent confidence levels.

\begin{tabular}{lcccc}
\hline $\begin{array}{l}\text { Trading Days } \\
\text { Around Closing }\end{array}$ & All & Traditional & Structured \\
PIPEs & PIPEs & 1,204 & Difference \\
\hline $\begin{array}{l}\text { Number of } \\
\text { PIPE Transactions }\end{array}$ & 3,783 & 2,579 & 0.40 & \\
\hline$[-4,5]$ & $3.87^{* * *}$ & $5.49^{* * *}$ & $(0.92)$ & $-5.09^{* * *}$ \\
& $(0.53)$ & $(0.65)$ & & $(1.13)$ \\
{$[6,100]$} & & -2.82 & $-14.37 * * *$ & $-11.55^{* * *}$ \\
& $-6.50^{* * *}$ & $(1.82)$ & $(2.57)$ & $(3.15)$ \\
{$[6,250]$} & $(1.49)$ & $-4.73^{*}$ & $-25.35 * * *$ & $-20.62^{* * *}$ \\
& $-11.30^{* * *}$ & $(2.81)$ & $(4.56)$ & $(5.36)$ \\
{$[6,500]$} & $(2.41)$ & $-13.03^{* * *}$ & $-38.83^{* * *}$ & $-25.79^{* * *}$ \\
& $-21.25^{* * *}$ & $(4.32)$ & $(5.45)$ & $(6.96)$ \\
\hline
\end{tabular}


Table 5: Abnormal Returns of PIPE Companies Using Different Benchmarks

This table summarizes the mean abnormal returns of the common stocks of companies issuing PIPEs by the major investors in the PIPE securities using various benchmarks. The standard errors for the means are reported in parentheses. The mean returns are expressed in percent. '*', '**', and '***' denote estimates that are statistically different from zero at the 10,5 , and 1 percent confidence levels.

Panel A: Short-Term Abnormal Returns [-4, 5]

\begin{tabular}{|c|c|c|c|c|}
\hline Benchmark & $\begin{array}{c}\text { All } \\
\text { PIPEs }\end{array}$ & $\begin{array}{l}\text { Traditional } \\
\text { PIPEs }\end{array}$ & $\begin{array}{l}\text { Structured } \\
\text { PIPEs }\end{array}$ & Difference \\
\hline $\begin{array}{l}\text { Fama-French Size and Book-to-Market } \\
\text { Portfolios }\end{array}$ & $\begin{array}{l}4.18^{* * *} \\
(0.46)\end{array}$ & $\begin{array}{l}6.09 * * * \\
(0.57)\end{array}$ & $\begin{array}{c}0.06 \\
(0.78)\end{array}$ & $\begin{array}{l}-6.03 * * * \\
(0.96)\end{array}$ \\
\hline Comparable Firm Match by Industry and Size & $\begin{array}{l}3.57 * * * \\
(0.53)\end{array}$ & $\begin{array}{l}5.29 * * * \\
(0.65)\end{array}$ & $\begin{array}{l}-0.10 \\
(0.88)\end{array}$ & $\begin{array}{l}-5.39 * * * \\
(1.10)\end{array}$ \\
\hline $\begin{array}{l}\text { Comparable Firm Match by Industry, Size, and } \\
\text { Book-to-Market }\end{array}$ & $\begin{array}{l}3.65^{* * *} \\
(0.53)\end{array}$ & $\begin{array}{l}5.71^{* * *} \\
(0.65)\end{array}$ & $\begin{array}{l}-0.75 \\
(0.91)\end{array}$ & $\begin{array}{l}-6.46^{* * *} \\
(1.12)\end{array}$ \\
\hline $\begin{array}{l}\text { Comparable Firm Match by Industry, Size, } \\
\text { Book-to-Market, and Momentum }\end{array}$ & $\begin{array}{l}3.87 * * * \\
(0.53)\end{array}$ & $\begin{array}{l}5.49 * * * \\
(0.65)\end{array}$ & $\begin{array}{c}0.40 \\
(0.92)\end{array}$ & $\begin{array}{l}-5.09 * * * \\
(1.13)\end{array}$ \\
\hline $\begin{array}{l}\text { Comparable Firm Match by Industry, Age, } \\
\text { Size, Book-to-Market, and Momentum }\end{array}$ & $\begin{array}{l}4.14 * * * \\
(0.54)\end{array}$ & $\begin{array}{l}5.77^{* * *} \\
(0.67)\end{array}$ & $\begin{array}{c}0.58 \\
(0.91)\end{array}$ & $\begin{array}{l}-5.19 * * * \\
(1.13)\end{array}$ \\
\hline $\begin{array}{l}\text { Difference between PIPEs and SEOs using } \\
\text { Comparable Firm Match by Industry, Size, } \\
\text { Book-to-Market, and Momentum }\end{array}$ & $\begin{array}{l}5.01^{* * *} \\
(0.61)\end{array}$ & $\begin{array}{l}6.63^{* * *} \\
(0.72)\end{array}$ & $\begin{array}{c}1.54 \\
(0.96)\end{array}$ & $\begin{array}{l}-5.09 * * * \\
(1.13)\end{array}$ \\
\hline
\end{tabular}

Panel B: Post-Close Abnormal Returns [6,500]

\begin{tabular}{lcccc}
\hline Benchmark & All & Traditional & Structured & Difference \\
& PIPEs & PIPEs & PIPEs & \\
\hline Fama-French Size and Book-to-Market & $-17.65^{* * *}$ & $-8.69^{* *}$ & $-36.86^{* * *}$ & $-28.17^{* * *}$ \\
Portfolios & $(2.43)$ & $(3.14)$ & $(3.56)$ & $(4.74)$ \\
& & & & \\
Comparable Firm Match by Industry and Size & $-35.78^{* * *}$ & $-25.43^{* * *}$ & $-57.94^{* * *}$ & $-32.51^{* * *}$ \\
& $(3.50)$ & $(4.14)$ & $(6.44)$ & $(7.66)$ \\
Comparable Firm Match by Industry, Size, and & $-22.79^{* * *}$ & $-13.91^{* * *}$ & $-41.82^{* * *}$ & $-27.91^{* * *}$ \\
Book-to-Market & $(3.31)$ & $(3.93)$ & $(6.14)$ & $(7.25)$ \\
Comparable Firm Match by Industry, Size, & $-21.25^{* * *}$ & $-13.04^{* * *}$ & $-38.83^{* * *}$ & $-25.79^{* * *}$ \\
Book-to-Market, and Momentum & $(3.44)$ & $(4.33)$ & $(5.45)$ & $(6.96)$ \\
Comparable Firm Match by Industry, Age, & $-23.58^{* * *}$ & $-17.56^{* * *}$ & $-35.52^{* * *}$ & $-17.96^{* *}$ \\
Size, Book-to-Market, and Momentum & $(3.79)$ & $(4.74)$ & $(6.14)$ & $(7.76)$ \\
Difference between PIPEs and SEOs using & $-16.86^{* * *}$ & $-8.65^{*}$ & $-34.45^{* * *}$ & $-25.79^{* * *}$ \\
Comparable Firm Match by Industry, Size, & $(4.46)$ & $(5.18)$ & $(6.15)$ & $(6.96)$ \\
Book-to-Market, and Momentum & & & & \\
\hline
\end{tabular}


Table 6: Abnormal Returns of Companies issuing PIPEs by Investor Type

This table summarizes the mean abnormal returns of the common stocks of companies issuing PIPEs by the major investors in the PIPE securities. The standard errors for the means are reported in parentheses. The mean returns are expressed in percent. '*', '**', and '***' denote estimates that are statistically different from zero at the 10,5 , and 1 percent confidence levels.

Panel A: Short-Term Abnormal Returns [-4, 5]

\begin{tabular}{|c|c|c|c|c|}
\hline & All PIPEs & $\begin{array}{l}\text { Traditional } \\
\text { PIPEs }\end{array}$ & $\begin{array}{l}\text { Structured } \\
\text { PIPEs }\end{array}$ & Difference \\
\hline Hedge Funds & $\begin{array}{c}1.42 \\
(0.91)\end{array}$ & $\begin{array}{l}3.73 * * * \\
(1.22)\end{array}$ & $\begin{array}{l}-0.43 \\
(1.30)\end{array}$ & $\begin{array}{l}-4.17 * * \\
(1.78)\end{array}$ \\
\hline $\begin{array}{l}\text { Non-Hedge Fund } \\
\text { Investors }\end{array}$ & $\begin{array}{l}5.66 * * * \\
(0.85)\end{array}$ & $\begin{array}{l}6.23 * * * \\
(0.95)\end{array}$ & $\begin{array}{c}2.44 \\
(1.83)\end{array}$ & $\begin{array}{l}-3.80^{*} \\
(2.06)\end{array}$ \\
\hline Corporations & $\begin{array}{l}9.38^{* * *} \\
(1.93)\end{array}$ & $\begin{array}{l}10.16^{* * *} \\
(2.03)\end{array}$ & $\begin{array}{l}-0.33 \\
(5.45)\end{array}$ & $\begin{aligned}-10.49 * \\
(5.82)\end{aligned}$ \\
\hline Mutual Funds & $\begin{array}{c}2.74 \\
(1.79)\end{array}$ & $\begin{array}{r}3.10^{*} \\
(1.88)\end{array}$ & $\begin{array}{l}-2.18 \\
(5.50)\end{array}$ & $\begin{array}{l}-5.28 \\
(5.81)\end{array}$ \\
\hline $\begin{array}{l}\text { Venture Capital and } \\
\text { Private Equity Funds }\end{array}$ & $\begin{array}{l}8.51^{* * *} \\
(2.72)\end{array}$ & $\begin{array}{l}10.80^{* * *} \\
(3.40)\end{array}$ & $\begin{array}{c}0.70 \\
(2.84)\end{array}$ & $\begin{array}{c}-10.10^{* *} \\
(4.43)\end{array}$ \\
\hline $\begin{array}{l}\text { Other Known } \\
\text { Investors }\end{array}$ & $\begin{array}{l}4.44^{* * *} \\
(1.07)\end{array}$ & $\begin{array}{l}4.55^{* * *} \\
(1.18)\end{array}$ & $\begin{array}{c}3.88 \\
(2.61)\end{array}$ & $\begin{array}{l}-0.67 \\
(2.86)\end{array}$ \\
\hline
\end{tabular}

Panel B: Post-Close Abnormal Returns [6,500]

\begin{tabular}{lcccc}
\hline & All PIPEs & $\begin{array}{c}\text { Traditional } \\
\text { PIPEs }\end{array}$ & $\begin{array}{c}\text { Structured } \\
\text { PIPEs }\end{array}$ & Difference \\
\hline Hedge Funds & $-30.38^{* * *}$ & $-17.88^{* * *}$ & $-40.38^{* * *}$ & $-22.50^{* *}$ \\
& $(4.72)$ & $(5.85)$ & $(7.06)$ & $(9.18)$ \\
\hline $\begin{array}{l}\text { Non-Hedge Fund } \\
\text { Investors }\end{array}$ & $-14.26^{* *}$ & -8.89 & $-44.34^{* * *}$ & $-35.45^{* * *}$ \\
\hline Corporations & $(5.80)$ & $(6.42)$ & $(13.01)$ & $(14.51)$ \\
& -8.37 & -9.64 & 7.46 & 17.10 \\
Mutual Funds & $(9.82)$ & $(10.44)$ & $(23.81)$ & $(26.00)$ \\
& & & & $-61.00^{*}$ \\
Venture Capital and & $(11.67$ & 12.79 & $(33.32)$ & $(35.27)$ \\
Private Equity Funds & $(13.10)$ & $(11.57)$ & $-65.44 * *$ & $-58.99 *$ \\
& & -6.45 & $(30.73)$ & $(33.88)$ \\
Other Known & -19.84 & $(14.27)$ & $-38.67 * *$ & -23.82 \\
Investors & $(9.01)$ & -14.85 & $(15.29)$ & $(18.50)$ \\
& & $(10.42)$ & & \\
\hline
\end{tabular}


Table 7: Determinants of Short- and Long-Term Stock Performance

This table summarizes the results of regressing the excess returns during several time periods around and after the close of the PIPE transaction on the characteristics of the PIPE. The excess returns are computed by subtracting the appropriate return of the six Fama-French size/book-to-market portfolios from the return of the individual stocks. All regressions include indicator variables for the years of the close of the deal and the industry sectors. The standard errors are robust, corrected for clustering of observations by the same company and are summarized in parentheses. '*', '**', and '***' denote estimates that are statistically different from zero at the 10,5 , and 1 percent confidence levels.

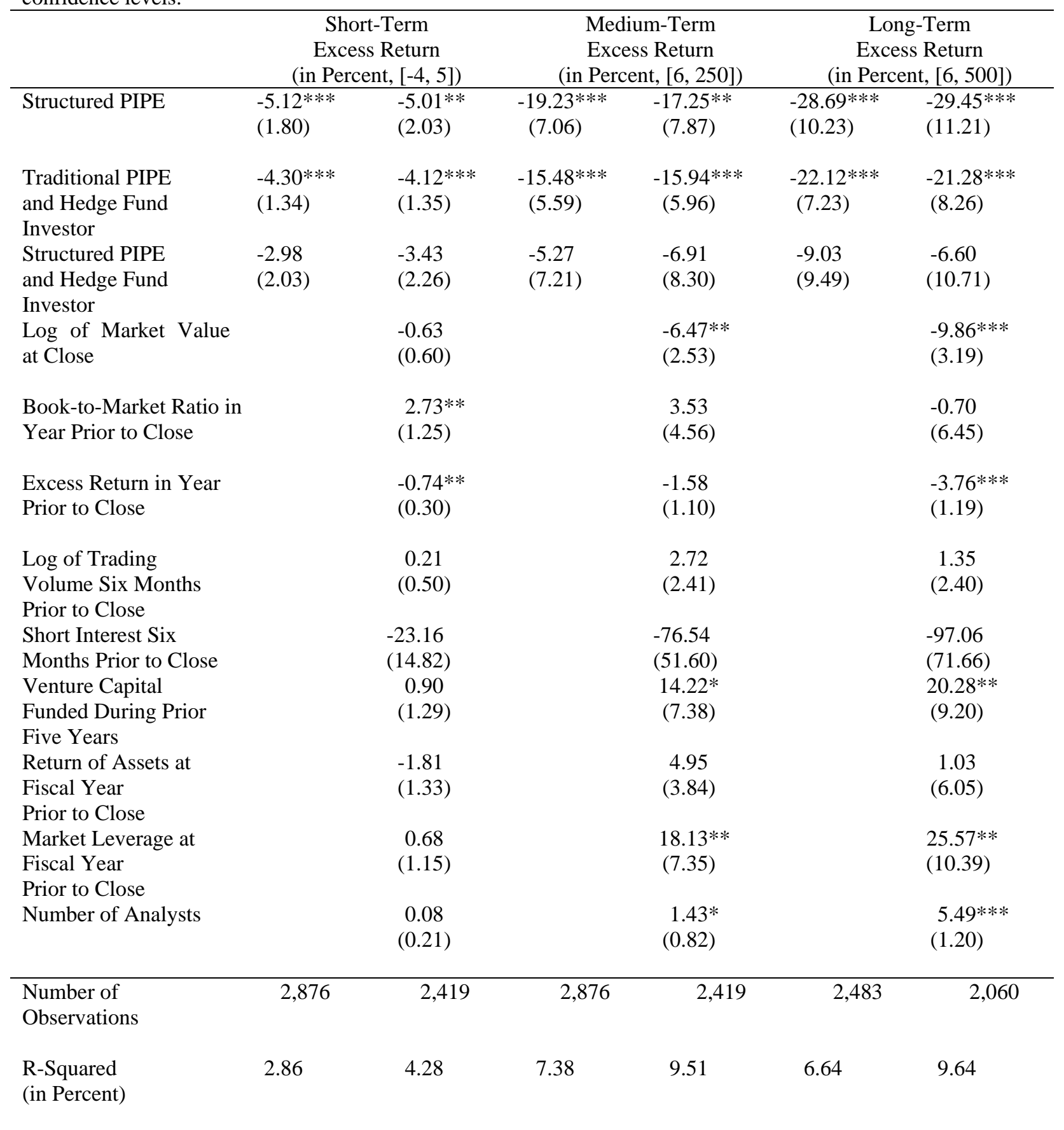


Table 8: Returns of Calendar Time Portfolios of Companies That Issue PIPEs

This table summarizes the abnormal returns of a portfolio that includes all the stocks of companies which closed a PIPE deal during the last 500 trading days.

The abnormal returns are expressed in percent and are annualized. The standard errors are summarized in parentheses. '*', '**', and '***' denote abnormal returns that are statistically different from zero at the 10, 5, and 1 percent confidence levels.

\begin{tabular}{|c|c|c|c|c|c|c|c|c|c|}
\hline \multirow{3}{*}{$\begin{array}{l}\text { Annualized } \\
\text { Abnormal } \\
\text { Performance } \\
\end{array}$} & \multicolumn{3}{|c|}{ All PIPEs } & \multicolumn{3}{|c|}{ Traditional PIPEs } & \multicolumn{3}{|c|}{ Structured PIPEs } \\
\hline & All & Non-Hedge & Hedge & All & Non-Hedge & Hedge & All & Non-Hedge & Hedge \\
\hline & Investors & Investors & Investors & Investors & Investors & Investors & Investors & Investors & Investors \\
\hline Excess Return & $-18.49 *$ & -11.83 & $-32.37 * * *$ & -8.54 & -7.24 & -16.50 & $-35.41 * * *$ & $-24.49 *$ & $-42.03 * * *$ \\
\hline Above Market & $(10.42)$ & (9.97) & $(11.62)$ & $(10.36)$ & (10.05) & $(12.45)$ & (11.78) & (12.59) & (12.16) \\
\hline CAPM Alpha & $\begin{array}{l}-21.75^{* *} \\
(9.77)\end{array}$ & $\begin{array}{r}-14.86 \\
(9.39)\end{array}$ & $\begin{array}{l}-35.85^{* * *} \\
(10.91)\end{array}$ & $\begin{array}{r}-11.41 \\
(9.73)\end{array}$ & $\begin{array}{l}-9.90 \\
(9.49)\end{array}$ & $\begin{array}{l}-19.77 * \\
(11.77)\end{array}$ & $\begin{array}{l}-39.98 * * * \\
(11.02)\end{array}$ & $\begin{array}{l}-28.69 * * \\
(12.04)\end{array}$ & $\begin{array}{l}-45.99 * * * \\
(11.47)\end{array}$ \\
\hline $\begin{array}{l}\text { 3-Factor Fama- } \\
\text { French Alpha }\end{array}$ & $\begin{array}{l}-16.81^{* * *} \\
(6.15)\end{array}$ & $\begin{array}{c}-10.52 * \\
(5.91)\end{array}$ & $\begin{array}{l}-29.78^{* * *} \\
(7.19)\end{array}$ & $\begin{array}{l}-6.98 \\
(6.24)\end{array}$ & $\begin{array}{l}-5.71 \\
(6.15)\end{array}$ & $\begin{array}{c}-13.99 * \\
(8.22)\end{array}$ & $\begin{array}{l}-33.79 * * * \\
(7.97)\end{array}$ & $\begin{array}{l}-24.81^{* *} \\
(10.00)\end{array}$ & $\begin{array}{l}-39.99 * * * \\
(8.58)\end{array}$ \\
\hline $\begin{array}{l}\text { 4-Factor } \\
\text { Carhart Alpha }\end{array}$ & $\begin{array}{l}-16.51^{* * *} \\
(6.29)\end{array}$ & $\begin{array}{r}-11.22 * \\
(6.02)\end{array}$ & $\begin{array}{l}-27.54 * * * \\
(7.35)\end{array}$ & $\begin{array}{l}-7.57 \\
(6.37)\end{array}$ & $\begin{array}{l}-6.71 \\
(5.87)\end{array}$ & $\begin{array}{c}-14.44^{*} \\
(8.42)\end{array}$ & $\begin{array}{l}-31.08 * * * \\
(8.16)\end{array}$ & $\begin{array}{l}-22.64 * * \\
(10.23)\end{array}$ & $\begin{array}{c}-36.05 * * * \\
(8.74)\end{array}$ \\
\hline $\begin{array}{l}\text { 4-Factor Ferson- } \\
\text { Schadt Alpha }\end{array}$ & $\begin{array}{l}-19.27 * * * \\
(6.08)\end{array}$ & $\begin{array}{l}-13.23^{* *} \\
(5.87)\end{array}$ & $\begin{array}{l}-29.61 * * * \\
(7.15)\end{array}$ & $\begin{array}{l}-9.92 \\
(6.26)\end{array}$ & $\begin{array}{l}-8.84 \\
(6.10)\end{array}$ & $\begin{array}{c}-16.53^{*} \\
(8.51)\end{array}$ & $\begin{array}{l}-34.62 * * * \\
(7.93)\end{array}$ & $\begin{array}{l}-24.91 * * \\
(10.61)\end{array}$ & $\begin{array}{c}-37.07 * * * \\
(8.59)\end{array}$ \\
\hline $\begin{array}{l}\text { 6-Factor Eckbo- } \\
\text { Masulis-Norli Alpha }\end{array}$ & $\begin{array}{c}-21.33^{* *} \\
(9.59)\end{array}$ & $\begin{array}{r}-14.51 \\
(9.27)\end{array}$ & $\begin{array}{l}-35.43^{* * *} \\
(10.76)\end{array}$ & $\begin{array}{r}-11.02 \\
(9.61)\end{array}$ & $\begin{array}{l}-9.56 \\
(9.40)\end{array}$ & $\begin{array}{l}-19.41^{*} \\
(11.72)\end{array}$ & $\begin{array}{l}-39.48^{* * *} \\
(10.76)\end{array}$ & $\begin{array}{l}-28.39 * * \\
(11.84)\end{array}$ & $\begin{array}{l}-45.51^{* * * *} \\
(11.28)\end{array}$ \\
\hline
\end{tabular}


Table 9: Accounting Performance of Companies that Issue PIPEs

This table summarizes the accounting performance during four years surrounding the PIPE transaction. The table summarizes the medians of the Return on Assets, the Book-to-Market ratio, and the Capital and R\&D Expenditures relative to Total Assets.

Panel A: Median Return on Assets (in Percent)

\begin{tabular}{lcccccc}
\hline Time Period & \multicolumn{2}{c}{ All PIPEs } & \multicolumn{2}{c}{ Traditional PIPEs } & \multicolumn{2}{c}{ Structured PIPEs } \\
& $\begin{array}{l}\text { Non-Hedge } \\
\text { Investors }\end{array}$ & $\begin{array}{c}\text { Hedge } \\
\text { Investors }\end{array}$ & $\begin{array}{c}\text { Non-Hedge } \\
\text { Investors }\end{array}$ & $\begin{array}{c}\text { Hedge } \\
\text { Investors }\end{array}$ & $\begin{array}{c}\text { Non-Hedge } \\
\text { Investors }\end{array}$ & $\begin{array}{c}\text { Hedge } \\
\text { Investors }\end{array}$ \\
\hline $\begin{array}{l}\text { Fiscal Year } \\
\text { Prior to PIPE Close }\end{array}$ & -36.3 & -39.7 & -35.0 & -38.8 & -44.8 & -50.4 \\
$\begin{array}{l}\text { Fiscal Year } \\
\text { of PIPE Close }\end{array}$ & -33.1 & -45.2 & -32.2 & -41.2 & -41.7 & -54.0 \\
$\begin{array}{l}\text { One Fiscal Year after } \\
\begin{array}{l}\text { PIPE Close } \\
\text { Two Fiscal Years after }\end{array}\end{array}$ & -27.9 & -47.4 & -25.7 & -37.9 & -46.0 & -50.3 \\
\begin{tabular}{l} 
PIPE Close \\
\hline
\end{tabular} & -26.2 & -42.9 & -23.1 & -32.5 & -42.9 & -48.4 \\
\hline
\end{tabular}

Panel B: Median Book to Market Ratio (in Percent)

\begin{tabular}{lcccccc}
\hline Time Period & \multicolumn{2}{c}{ All PIPEs } & \multicolumn{2}{c}{ Traditional PIPEs } & \multicolumn{2}{c}{ Structured PIPEs } \\
& $\begin{array}{l}\text { Non-Hedge } \\
\text { Investors }\end{array}$ & $\begin{array}{c}\text { Hedge } \\
\text { Investors }\end{array}$ & $\begin{array}{c}\text { Non-Hedge } \\
\text { Investors }\end{array}$ & $\begin{array}{c}\text { Hedge } \\
\text { Investors }\end{array}$ & $\begin{array}{c}\text { Non-Hedge } \\
\text { Investors }\end{array}$ & $\begin{array}{c}\text { Hedge } \\
\text { Investors }\end{array}$ \\
\hline $\begin{array}{l}\text { Fiscal Year } \\
\text { Prior to PIPE Close }\end{array}$ & 23.5 & 19.6 & 24.7 & 21.0 & 16.7 & 18.4 \\
$\begin{array}{l}\text { Fiscal Year } \\
\text { of PIPE Close }\end{array}$ & 25.6 & 21.5 & 26.6 & 23.5 & 20.2 & 19.7 \\
$\begin{array}{l}\text { One Fiscal Year after } \\
\begin{array}{l}\text { PIPE Close } \\
\text { Two Fiscal Years after }\end{array}\end{array}$ & 27.3 & 22.0 & 28.5 & 25.1 & 15.3 & 19.4 \\
PIPE Close & 26.5 & 21.6 & 27.9 & 25.8 & 16.5 & 19.2 \\
\hline
\end{tabular}

Panel C: Median Capital and R\&D Expenditures Relative to Total Assets (in Percent)

\begin{tabular}{lcccccc}
\hline Time Period & \multicolumn{2}{c}{ All PIPEs } & \multicolumn{2}{c}{ Traditional PIPEs } & \multicolumn{2}{c}{ Structured PIPEs } \\
& $\begin{array}{l}\text { Non-Hedge } \\
\text { Investors }\end{array}$ & $\begin{array}{c}\text { Hedge } \\
\text { Investors }\end{array}$ & $\begin{array}{c}\text { Non-Hedge } \\
\text { Investors }\end{array}$ & $\begin{array}{c}\text { Hedge } \\
\text { Investors }\end{array}$ & $\begin{array}{c}\text { Non-Hedge } \\
\text { Investors }\end{array}$ & $\begin{array}{c}\text { Hedge } \\
\text { Investors }\end{array}$ \\
\hline $\begin{array}{l}\text { Fiscal Year } \\
\text { Prior to PIPE Close }\end{array}$ & 20.6 & 23.7 & 21.2 & 25.1 & 20.6 & 21.7 \\
$\begin{array}{l}\text { Fiscal Year } \\
\text { of PIPE Close }\end{array}$ & 18.2 & 20.9 & 17.7 & 20.7 & 21.6 & 20.4 \\
$\begin{array}{l}\text { One Fiscal Year after } \\
\begin{array}{l}\text { PIPE Close } \\
\text { Two Fiscal Years after }\end{array}\end{array}$ & 17.2 & 18.9 & 16.2 & 18.7 & 18.9 & 19.9 \\
PIPE Close & 16.8 & 18.7 & 15.8 & 17.7 & 19.2 & 19.0 \\
\hline
\end{tabular}




\section{Table 10: Determinants of Accounting Performance}

This table summarizes the determinants of the accounting performance of companies issuing PIPEs during two time periods after the close of the PIPE transaction. We report the ordinary least squares regression of the return on assets at three different time periods on past characteristics of companies. The return on assets is winsorized at the 1 percent level. All regressions include indicator variables for the years of the close of the deal and the industry sectors. The standard errors are robust, corrected for clustering of observations by the same company and are summarized in parentheses. '*', '**', and '***' denote estimates that are statistically different from zero at the 10, 5 , and 1 percent confidence levels.

\begin{tabular}{|c|c|c|}
\hline \multirow[t]{2}{*}{ Dependent Variable } & \multicolumn{2}{|c|}{ Return on Assets (in Percent): } \\
\hline & $\begin{array}{l}\text { During the First Fiscal Year after } \\
\text { the PIPE Issuance }\end{array}$ & $\begin{array}{l}\text { During the Second Fiscal Year after the } \\
\text { PIPE Issuance }\end{array}$ \\
\hline Structured PIPE & $\begin{array}{l}-25.14^{*} \\
(14.90)\end{array}$ & $\begin{array}{l}-15.59 \\
(11.73)\end{array}$ \\
\hline $\begin{array}{l}\text { Traditional PIPE and } \\
\text { Hedge Fund Investor }\end{array}$ & $\begin{array}{l}-21.36 * * \\
(9.04)\end{array}$ & $\begin{array}{c}1.81 \\
(7.13)\end{array}$ \\
\hline $\begin{array}{l}\text { Structured PIPE and } \\
\text { Hedge Fund Investor }\end{array}$ & $\begin{array}{l}-12.71 \\
(17.30)\end{array}$ & $\begin{array}{c}-8.58 \\
(14.24)\end{array}$ \\
\hline Log of Market Value at Close & $\begin{array}{c}3.68 \\
(4.93)\end{array}$ & $\begin{array}{c}3.74 \\
(3.36)\end{array}$ \\
\hline $\begin{array}{l}\text { Book-to-Market Ratio at Fiscal Year } \\
\text { Prior to Close }\end{array}$ & $\begin{array}{c}7.04 \\
(7.48)\end{array}$ & $\begin{array}{l}11.72 * * \\
(5.39)\end{array}$ \\
\hline $\begin{array}{l}\text { Excess Return During Year Prior to } \\
\text { Close }\end{array}$ & $\begin{array}{l}5.44 * * * \\
(1.71)\end{array}$ & $\begin{array}{c}0.52 \\
(1.53)\end{array}$ \\
\hline $\begin{array}{l}\text { Log of Trading Volume Six Months } \\
\text { Prior to Close }\end{array}$ & $\begin{array}{l}-1.30 \\
(3.63)\end{array}$ & $\begin{array}{l}-4.70 \\
(3.26)\end{array}$ \\
\hline $\begin{array}{l}\text { Short Interest Six Months Prior to } \\
\text { Close }\end{array}$ & $\begin{array}{c}-11.26 \\
(121.66)\end{array}$ & $\begin{array}{c}41.68 \\
(100.25)\end{array}$ \\
\hline $\begin{array}{l}\text { Venture Capital Funded During } \\
\text { Prior Five Years }\end{array}$ & $\begin{array}{c}2.93 \\
(7.86)\end{array}$ & $\begin{array}{l}-3.48 \\
(9.17)\end{array}$ \\
\hline $\begin{array}{l}\text { Return of Assets at Fiscal Year Prior } \\
\text { to Close }\end{array}$ & $\begin{array}{l}53.97 * * * \\
(11.33)\end{array}$ & $\begin{array}{l}55.93^{* * *} \\
(8.90)\end{array}$ \\
\hline $\begin{array}{l}\text { Market Leverage at Fiscal Year } \\
\text { Prior to Close }\end{array}$ & $\begin{array}{l}31.39 * * * \\
(9.12)\end{array}$ & $\begin{array}{l}21.96^{*} \\
(11.93)\end{array}$ \\
\hline Number of Analysts & $\begin{array}{l}4.42 * * * \\
(1.23)\end{array}$ & $\begin{array}{l}3.04^{* * *} \\
(1.01)\end{array}$ \\
\hline Number of Observations & 2,012 & 1,515 \\
\hline R-Squared (in Percent) & 14.04 & 15.85 \\
\hline
\end{tabular}


Table 11: Abnormal Returns of Companies Issuing PIPEs by Detailed Security Type

This table summarizes the mean abnormal returns of the common stocks of companies issuing PIPEs by the detailed security type. The mean returns are expressed in percent. The standard errors for the means are reported in parentheses. '*', '**', and '***' denote estimates that are statistically different from zero at the 10,5 , and 1 percent confidence levels.

Panel A: Traditional PIPEs

\begin{tabular}{lccc}
\hline Security & Number of PIPEs & $\begin{array}{c}\text { Short-Term Abnormal } \\
\text { Return } \\
{[-4,5]}\end{array}$ & $\begin{array}{c}\text { Post-Close } \\
\text { Abnormal Return } \\
{[6,500]}\end{array}$ \\
\hline Common Stock & 1,604 & $\begin{array}{c}6.54^{* * *} \\
(0.75)\end{array}$ & $-12.11^{* *}$ \\
& & $6.15)$ \\
Fixed Convertible Preferred & 510 & $6.73^{* * *}$ & $-13.17^{*}$ \\
Stock & & $(1.94)$ & $(7.47)$ \\
Fixed Convertible Debt & \multirow{2}{*}{344} & 0.28 & -13.62 \\
& & $(1.69)$ & $(9.71)$ \\
Common Stock - & \multirow{2}{*}{121} & 1.18 & $-23.18^{* *}$ \\
Shelf Sale & & $(2.36)$ & $(10.91)$ \\
\end{tabular}

Panel B: Structured PIPEs

\begin{tabular}{lccc}
\hline Security & Number of PIPEs & $\begin{array}{c}\text { Short-Term Abnormal } \\
\text { Return } \\
{[-4,5]}\end{array}$ & $\begin{array}{c}\text { Post-Close } \\
\text { Abnormal Return } \\
{[6,500]}\end{array}$ \\
\hline $\begin{array}{l}\text { Floating Convertible Preferred } \\
\text { Stock }\end{array}$ & 536 & 0.42 & $-42.51^{* * *}$ \\
Floating Convertible Debt & 277 & $(1.41)$ & $(9.27)$ \\
& & $4.03^{* *}$ & $-36.55^{* *}$ \\
Structured Equity Lines & 172 & $(1.83)$ & $(10.22)$ \\
& & -1.26 & $-29.00^{* *}$ \\
Common Stock - & & $(2.26)$ & $(11.39)$ \\
Reset & 84 & 0.69 & $-41.10^{* *}$ \\
Reset Convertible Preferred & & $(2.88)$ & $(16.92)$ \\
Stock & 80 & -4.01 & $-35.86^{* *}$ \\
Reset Convertible Debt & & $(3.10)$ & $(16.57)$ \\
& 47 & -8.41 & -47.16 \\
& & $(6.47)$ & $(33.55)$ \\
\hline
\end{tabular}


Figure 1: Performance of Companies Issuing PIPEs by Security Type

The Figure depicts the average abnormal buy-and-hold return of companies that issue PIPEs.

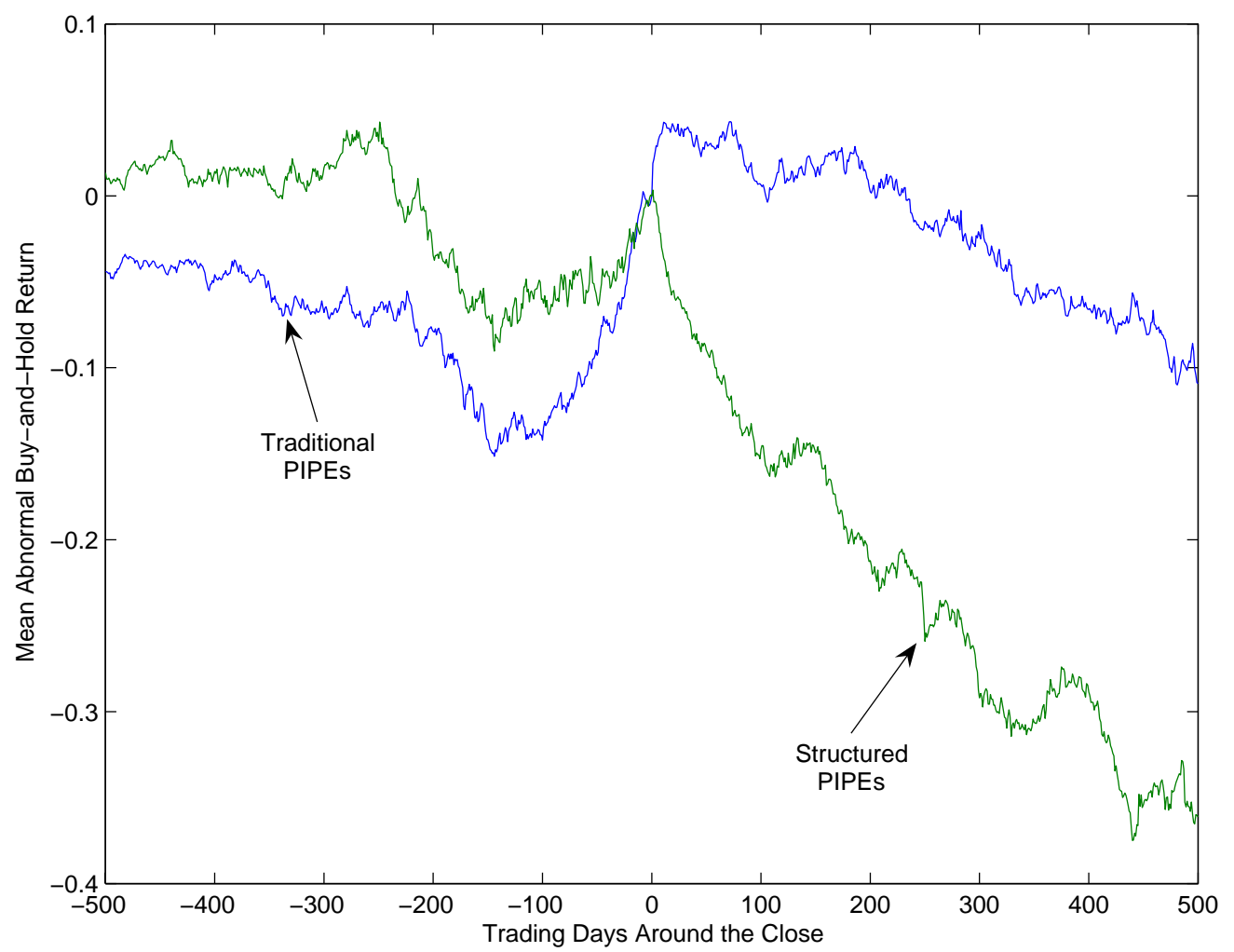


Figure 2: Distribution of Performance of Companies Issuing PIPEs by Security Type This figure depicts the cumulative probabilities of the average abnormal buy-and-hold returns of companies that issue PIPEs. The buy-and-hold returns are computed over the 250 trading days following the close of the PIPE.

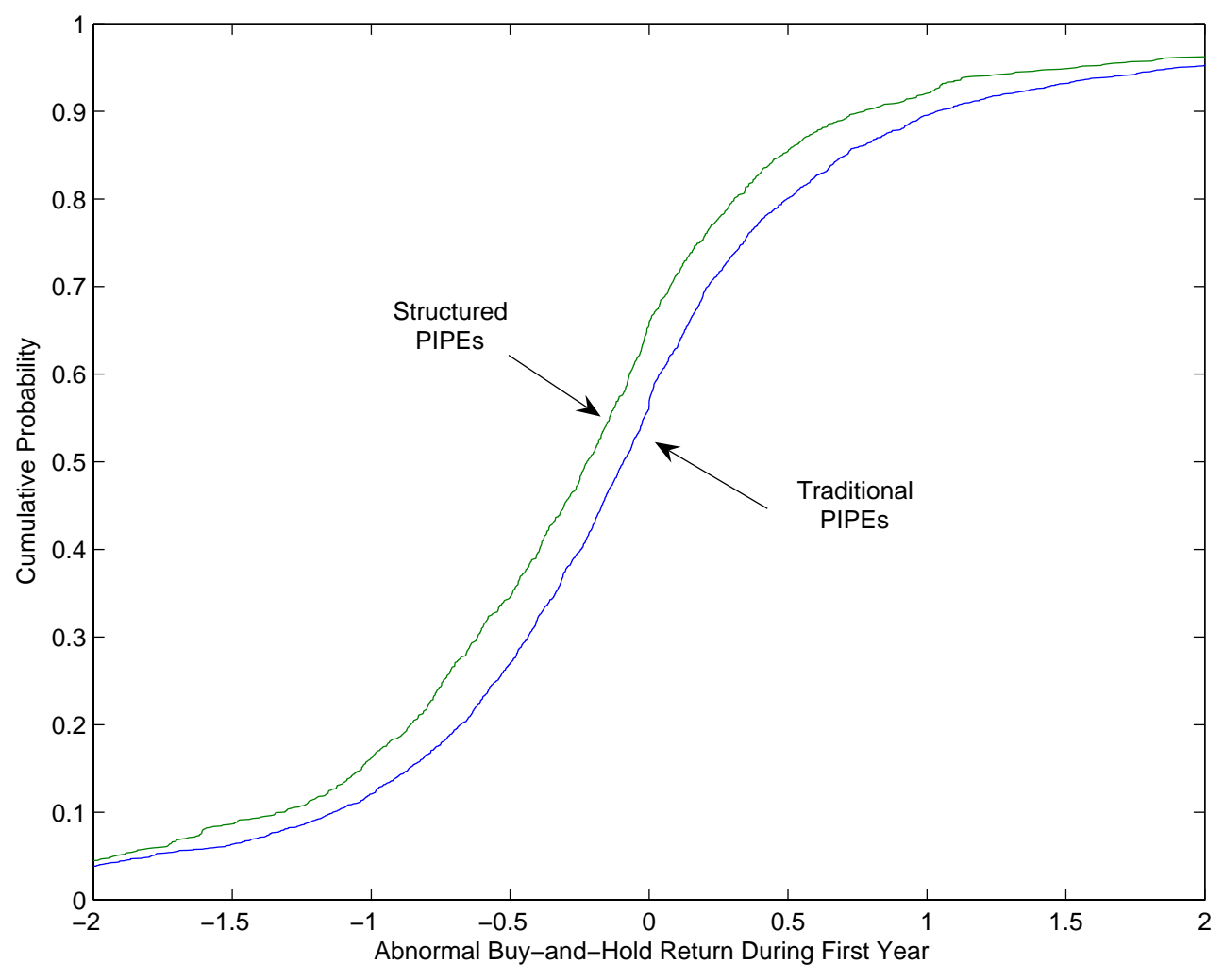


Figure 3: Short Interest for Companies Issuing PIPEs

We depict the difference in the short interest of companies issuing PIPEs compared to matched companies. Companies are matched according to industry, size, book-to-market ratio, and momentum. Short interest is defined as the proportion of shares sold short relative to shares outstanding.
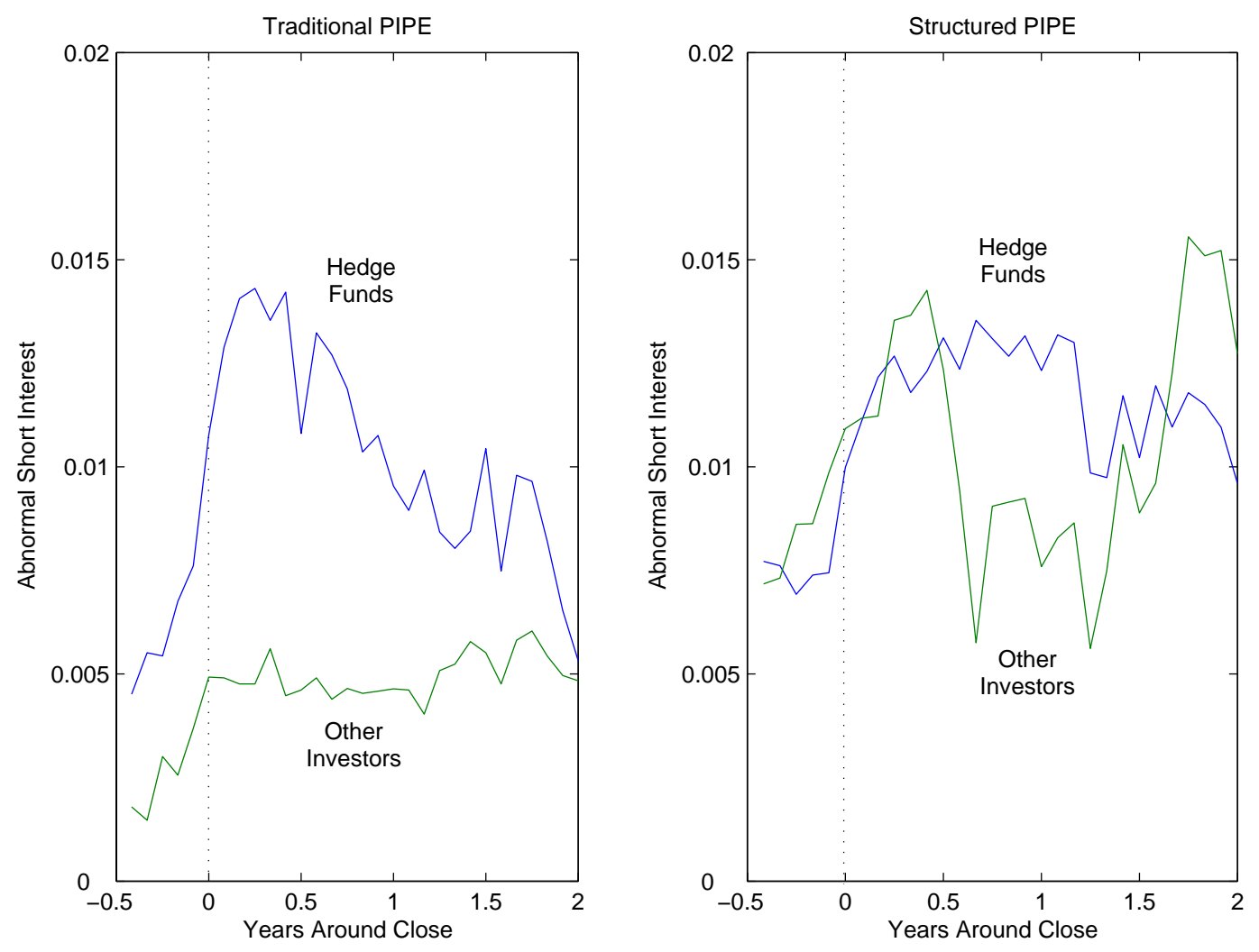